University of Texas at El Paso

DigitalCommons@UTEP

Working Papers

Center for Education Research and Policy Studies

(CERPS)

Spring 2016

\title{
Are School Districts Allocating Resources Equitably? The Every Student Succeeds Act, Teacher Experience Gaps, and Equitable Resource Allocation
}

David S. Knight

University of Texas at El Paso, dsknight@utep.edu

Follow this and additional works at: https://digitalcommons.utep.edu/cerps_wp

Part of the Education Policy Commons

Comments:

CERPS Working Paper \#2016-2

This working paper is now forthcoming in Education Policy and is available online at http://journals.sagepub.com/doi/abs/10.1177/0895904817719523.

\section{Recommended Citation}

Knight, David S., "Are School Districts Allocating Resources Equitably? The Every Student Succeeds Act, Teacher Experience Gaps, and Equitable Resource Allocation" (2016). Working Papers. 3.

https://digitalcommons.utep.edu/cerps_wp/3 
CEPRS Working

Paper

WP \#2016-2

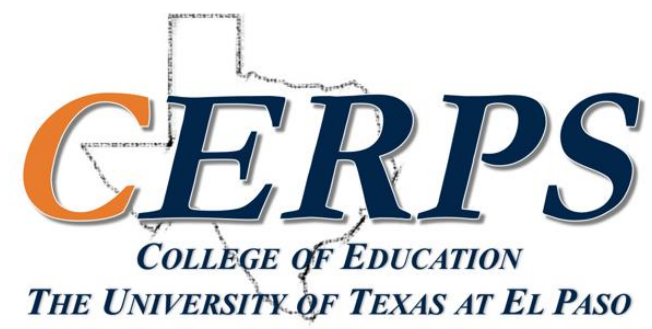

\section{Are School Districts Allocating Resources Equitably? The Every Student Succeeds Act, Teacher Experience Gaps, and Equitable Resource Allocation}

David S. Knight

Center for Education Research and Policy Studies

University of Texas at El Paso

Center for Education Research and Policy Studies

College of Education, Suite 105

University of Texas at El Paso | 500 W. University Ave. | El Paso, TX 79968

(915) 747-5949

http://www.utep.edu/education/cerps/ 


\section{Acknowledgements}

This material is based upon work supported by the National Science Foundation under Grant No. 1661097 and the W. T. Grant Foundation under Grant No. 186848. The author also acknowledges funding from the University of Texas at El Paso College of Education and Office of the Provost.

CERPS working papers have not undergone final formal peer review and should be cited as working papers. They are intended to encourage discussion and suggestions for revision before final publication. The views expressed in this paper do not necessarily reflect those of the University of Texas at El Paso or the College of Education. The authors are responsible for any errors.

This working paper is now forthcoming in Education Policy and is available online at http://journals.sagepub.com/doi/abs/10.1177/0895904817719523.

Suggested Citation:

Knight, D. S. (Forthcoming). Are school districts allocating resources equitably? The Every Student Succeeds Act, teacher experience gaps, and equitable resource allocation. Educational Policy. Advance online publication. DOI: 10.1177/0895904817719523 


\begin{abstract}
Ongoing federal efforts support equalizing access to experienced educators for low-income students and students of color, thereby narrowing the "teacher experience gap." I show that while high-poverty and high-minority schools have larger class sizes and receive less funding nationally, school districts allocate resource equitably, on average, across schools. However, the least experienced teachers are still concentrated in high-poverty and high-minority schools, both across and within districts. I then show that additional state and local funding is associated with more equitable district resource allocation. The study offers recommendations for state and federal education policy related to the Every Student Succeeds Act.
\end{abstract}


Are School Districts Allocating Resources Equitably?

The Every Student Succeeds Act, Teacher Experience Gaps, and Equitable Resource Allocation

Lack of access to high-quality instructional resources prevents students from receiving

adequate opportunities to learn (Darling-Hammond, 2000; 2004). Decades of research have

documented unequal funding and inequitable access to experienced, high-quality educators

across student race/ethnicity and socioeconomic status (e.g., Baker, Farrie, Johnson, Luhm, \&

Sciarra, 2017; Clotfelter, Ladd, Vigdor, \& Wheeler, 2006; Reardon, 2011). Because teachers are

typically paid according to a district-level salary schedule, unequal funding within school

districts is directly linked to the inequitable distribution of teacher experience across schools.

The U.S. Department of Education (U.S. DOE) currently uses two approaches to place more experienced educators in high-poverty, Title I schools, thereby narrowing the "teacher experience gap.” As part of the implementation process for the recently enacted Every Student Succeeds Act (ESSA), the DOE established new regulations that would require struggling districts to allocate equal teacher salary funding in high- and low-poverty schools. ${ }^{1}$ In addition, a federal program, State Plans to Ensure Equitable Access to Excellent Educators (U.S. DOE, 2014), requires states education agencies to measure students' access to high-quality and experienced teachers, and develop plans for closing within-district teacher quality gaps.

The purpose of this study is to assess the extent to which teacher salary spending, teacher experience, and teacher-student ratios are equitably distributed within school districts nationally and to identify factors associated with these patterns. Analyses focus on the role of district-level

\footnotetext{
${ }^{1}$ ESSA is the most recent reauthorization of the Elementary and Secondary Education Act, initially passed during the 1960s War of Poverty. The largest educational grant program is Title I, which targets funding to the nation's most impoverished schools. Title I schools refer to schools selected to receive Title I funding. Title I funding for higher-poverty schools falls under Title I, Part A. I refer to Title I, Part A simply as Title I throughout this article. As part of the implementation of ESSA, the DOE is required to write the specific rules for how the law should be implemented in states and districts, and how districts can use Title I funding.
} 
funding in narrowing gaps in teacher resources. The study has direct implications for the regulatory requirements of ESSA and state-level education policy. First, the study shows the extent to which districts currently allocate teacher salary funds equitably across schools and the types of districts with the largest funding gaps. A recent Brookings policy brief argued that districts already allocate the same level of funding to high- and low-poverty schools, on average, and requiring districts to do so would have no major impact on resource allocation (Dynarski \& Kainz, 2016). In contrast, other studies identify large numbers of districts that do not provide equitable teacher salary funding across schools (e.g., Heuer \& Stullich, 2011). Second, analyses of teacher experience gaps, and factors associated with those gaps, shed light on potential policy levers for increasing equity in the distribution of experienced teachers within school districts. State education agencies across the nation are implementing plans for enhancing access to effective educators in high-poverty schools. Meanwhile, several recent high-profile legal cases have argued that state laws pertaining to teacher tenure create teacher experience gaps, especially in large urban school districts (e.g., Vergara v. California; Wright v. New York). This study is the first to directly explore the relationship between district-level resources and school-level teacher resource gaps.

I link recently released data from the Office of Civil Rights to other national datasets to measure "teacher resource gaps" - inequitable distributions of teacher salary spending, teacher experience, and teacher-student ratios - for low-income students and students of color nationally. I then estimate models that predict district-level teacher resource gaps based on district characteristics. This second set of analyses focus specifically on factors that may allow districts to improve working conditions in their most difficult-to-staff schools such as per-pupil district funding, teacher salaries, and expenditures. The following research questions anchor the study: 
(1) To what extent are teacher salary funding, teacher experience, and student-teacher ratios, equitably distributed within school districts?

(2) To what extent is district per-student funding associated with teacher resource gaps between high- and low-poverty schools and between high- and low-minority schools within districts?

Findings show that on average nationally, higher-poverty schools have less funding per student for teacher salaries, lower proportions of experienced teachers, and fewer teachers per student, compared to lower-poverty schools, even when controlling for district-level cost factors and comparing schools within the same state. The same findings hold for students who identify as an underrepresented minority (Black, Latina/o, Native American, Pacific Islander/Hawaiian native, or more than one race) and when comparing Title I schools to non-Title I schools.

However, when comparing schools within the same district, a different pattern emerges. Districts spend more on teacher salaries per student and have more teachers per student in their higher-poverty and higher-minority schools, but have less experienced teachers, compared to more advantaged schools in the same district. In other words, districts make up for the fact that their most novice teachers are concentrated in higher-poverty schools by lowering average class sizes in those schools, and as a result, spend more per student on teacher salaries in higher need schools. These findings align with the federal "Comparability Rule," which requires districts to allocate equal teacher-student ratios in Title I and non-Title I schools. However, these averages mask substantial variation in district teacher resource gaps. Among districts with at least four elementary schools, for example, $20 \%$ have large teacher salary gaps (i.e., allocate at least $10 \%$ less teacher salary funding per student to their highest-poverty elementary schools compared to their lowest-poverty elementary schools). Finally, I find that greater levels of resources at the district level, as measured by per-pupil funding, average teacher salaries, or expenditures per 
pupil relative to other districts in the same state or county, are all associated with smaller teacher experience gaps and more equitable resource allocation patterns within districts.

These findings have important policy implications at the federal, state, and local level. Previously established federal regulations required districts with schools in need of “comprehensive support and improvement" and schools with low-performing subgroups (as determined in state accountability plans), to address resource inequities including both teacher experience gaps and disparities in funding across schools. ${ }^{2}$ However, in March 2017, Congress blocked all regulations for implementing ESSA established under the Obama Administration. One week later, the DOE released a new set of regulations that excludes the requirements that lower-performing districts take steps to address funding disparities across schools. Removal of these federal regulations places greater responsibility on state policymakers to monitor school district resource allocation. Results from this study suggest that one of five districts across the country currently have substantial resource inequities. At the same time, as others have noted (e.g., Gordon, 2016), requiring that districts spend equal dollars across schools could lead them to use forced teacher placements or continue lowering student-staffing ratios in high-poverty schools without addressing the underlying problem of high attrition in those schools. Lastly, findings suggest that one potential policy lever for helping districts equalize spending across schools and improving disadvantaged students' access to experienced teachers may be through increasing state or federal funding for school districts.

In the remainder of this paper, I first explore past research on the allocation of funding across schools and distribution of teacher experience within school districts. I then provide additional background on the changes included in ESSA and the DOE's process of "negotiated

\footnotetext{
2 These requirements are described in Section 200.21 of ESSA, with further documentation included in the DOE's final regulations (https://ed.gov/policy/elsec/leg/essa/essaaccountstplans1129.pdf).
} 
rulemaking." The subsequent sections describe the data and analytic approaches, findings, policy recommendations, and conclusions.

\section{Literature Review}

The study contributes to two areas of research. The first pertains to within-district resource allocation and the second focuses specifically on equitable access to more experienced or more effective teachers within school districts.

\section{Allocation of Funding across Schools}

Due to a lack of wide scale data on school expenditures, most school finance studies compare educational expenditures across districts (e.g., Baker \& Corcoran, 2012; Imazeki \& Reschovsky, 2001; Knight, Forthcoming). Some researchers have conducted in-depth case studies of school districts based on their own collected data (e.g., Haxton, de los Reyes, Chambers, Levin \& Cruz, 2012; Roza, 2008; Roza \& Hill, 2004; Roza, Miller \& Hill, 2005). The districts sampled in these studies generally allocate as least as many instructional staff per pupil in high-poverty (or Title I) schools as in their low-poverty (or non-Title I) schools, thereby complying with the Title I Comparability Rule. However, the clustering of less experienced teachers in higher-poverty schools creates an inequitable distribution of per-student teacher salary funding. Given the limited number of districts included in these analyses however, the studies do not shed light on how pervasive this problem is nationally, or what district characteristics are associated with resource and teacher experience gaps between high- and lowpoverty schools.

The American Recovery and Reinvestment Act of 2009 included funding to collect, for the first time, national data on school-level expenditures (all prior national school finance data were district-level or based on samples of schools). The DOE subsequently released a report 
finding that about half of higher-poverty schools received less state and local funding than lowerpoverty schools in the same district and grade level. Similarly, over $40 \%$ of Title I schools had lower state and local personnel expenditures per pupil than non-Title I schools in the same district and grade level (Heuer \& Stullich, 2011). These findings comport with other studies drawing on the same data (Government Accountability Office, 2011; Hanna et al., 2015; SpatigAmerikaner, 2012). In each study, the authors argue that the DOE should strengthen the Comparability requirement within Title I to require districts to allocate equal state and local funding for teacher salaries across Title-I and non-Title I schools (or across high- and lowpoverty schools).

Two reports are based on the more recently released Civil Rights Data Collection project, which collected school-level expenditure and teacher salary data for the 2013-14 school year (Dynarski \& Kainz, 2016; Office of Civil Rights, 2016). The First Look report, from the Office of Civil Rights (2016) finds that across all schools nationally, low-income students and students of color attend schools with less experienced and more chronically absent teachers. This initial report did not compare schools within the same district. A recent Brookings policy brief based on these same data (Dynarski \& Kainz, 2016) found that on average, districts allocate equal amounts of state and local funding for teacher salaries in high- and low-poverty schools and in Title I and in non-Title I schools. The authors conclude that mandating districts to provide equal per-pupil funding for teachers across schools is like "pushing on a string," as it would not lead to any substantial changes in within-district resource allocation (Dynarski \& Kainz, 2016).

However, that study did not examine variation across districts in the relationship between school demographics and school-level funding. That is, there may be large numbers of districts with 
inequitable resource allocation patterns even if data show that on average, districts are allocating teacher salary expenditures evenly across high- and low-poverty schools.

More broadly, none of the prior studies have examined district characteristics associated with teacher expenditure and experience gaps. For example, higher-poverty districts or those receiving less state and local funding may have larger teacher experience gaps. Similarly, expenditure gaps may be concentrated in certain states. In sum, the simple average relationships presented in Dynarski and Kainz (2016) or the summary statistics presented in past analyses mask important variation in various teacher resource gaps that have implications for federal, state, and local policymaking. For example, if districts with larger teacher resource gaps are clustered in particular states that share educational policies, then state policies may serve as a potential policy lever. Conversely, if particular district characteristics are associated with inequitable resource allocation (e.g., funding levels and teacher salaries, urbanicity, enrollment size, or poverty level), then federal policy could be refined to help increase resource allocation equity in specific types of districts, or states could target interventions to districts that tend to have larger teacher resource gaps.

\section{Distribution of Teacher Experience Across Schools}

As noted earlier, because teacher salaries are typically based on experience, the distribution of teacher experience across schools within districts largely determines how funding is distributed within districts. A large body of research shows that teacher experience, aptitude, and qualifications are all inequitably distributed across schools (Baker \& Green, 2015; Clotfelter et al., 2006; Darling-Hammond, 2000, 2004; Knight \& Strunk, 2016; Lankford, Loeb, \& Wyckoff, 2002; Peske \& Haycock, 2006). More recent studies show that teacher effectiveness as measured by value-added scores, which estimate teachers' contribution to student 
achievement gains on test scores - is also distributed inequitably (e.g., Glazerman \& Max, 2011; Isenberg et al., 2013; Sass, Hannaway, Xu, Figlio \& Feng, 2010). Most of these studies use detailed administrative data from one or several districts. A small number of studies examine teacher experience / quality gaps in districts across an entire state (Clotfelter, Ladd, Vigdor \& Wheeler, 2006; Goldhaber et al., 2015; Goldhaber, Quince \& Theobald, 2016), but no recent studies examine teacher experience gaps in all states nationally.

Several factors contribute to the inequitable distribution of teacher experience within school districts (Boyd, Lankford, Loeb \& Wyckoff, 2005; Ladd, 2011; Krieg, Theobald \& Goldhaber, 2015; Scafidi, Sjoquist \& Stinebrickner, 2007). Both the initial match of educators to schools and lower retention rates in high-need schools contribute to the teacher experience gap. Less supportive school administration, greater accountability pressure, and unprofessional work environments are all associated with higher teacher attrition within school districts (Boyd et al., 2011; Clotfelter, Ladd, Vigdor \& Dias, 2004; Johnson, Kraft \& Papay, 2012; Hanushek, Kain \& Rivkin, 2004). Some researchers contend that restrictive teacher contracts contribute to inequitable access to experienced teachers (Anzia \& Moe, 2014; Goldhaber et al., 2015), although others find no such evidence (e.g., Cohen-Vogel et al., 2013). Despite the many studies examining teacher attrition and inequitable distributions of teacher experience within school districts, no studies systematically assess district characteristics associated with larger teacher experience gaps.

A federal program to reduce district-level teacher quality gaps requires state education agencies to measure teacher quality gaps and identify potential root causes (State Plans to Ensure Equitable Access to Excellent Educators, DOE, 2014). The initiative lists primarily school-level issues as potential root causes of teacher quality gaps such as poor teacher recruitment strategies, 
school working conditions, and school leadership, but does not consider differences in state funding and teacher salary levels across districts (see Baker and Weber, 2016 for further discussion). Because state legislatures govern the district finance system, states education agencies are limited in their ability to alter teacher salaries or district funding levels.

At the same time, greater levels of funding or higher district teacher salaries may contribute to the narrowing of within-district teacher resource gaps for several reasons. Many studies show, for example, that competitive salaries and lower teacher-student ratios or class sizes help districts attract and retain teachers (Eller, Doerfler \& Meier, 2000; Gritz \& Theobald, 1996; Hanushek, Kain \& Rivkin, 2004; Loeb, Darling-Hammond \& Luczack, 2005; Murnane \& Olsen, 1989; Imazeki, 2005). On the one hand, greater resource levels permit districts to provide higher salaries and may allow district leaders to support school administrators in fostering more attractive working environments in schools with high teacher turnover. Principals can, in turn, provide more planning or collaborative meeting time for teachers, lower student loads, and provide additional opportunities for professional development - conditions that studies link to positive working conditions (Baker \& Weber, 2015; Johnson, Kraft \& Papay, 2012; Ladd, 2011). On the other hand, districts with lower resource levels may lose teachers to other districts in the same labor market that have resource advantages. Teacher experience gaps would expand if this form of attrition is concentrated in high-poverty or high-minority schools. In short, evidence suggests the potential for district resources to play an important role in narrowing teacher quality gaps within school districts.

Despite research and policy efforts to understand factors associated with district-level teacher quality gaps, no prior studies have systematically assessed the extent to which students have equitable access to experienced teachers nationally or whether district-level resources help 
districts equalize teacher resources across high- and low-poverty schools or across schools with higher concentrations of students of color. The current study builds off prior work by measuring teacher resource gaps in school districts nationally and exploring factors associated with these gaps. The study is particularly timely given the recent regulatory requirements established by the DOE as part of the implementation of ESSA (Ujifusa, \& Klein, 2016) ${ }^{3}$ and the ongoing federal and state policy debates surrounding educator quality gaps. I next provide additional background on the policy context underlying this study.

\section{Policy Context}

Over the past four decades, policymakers in the U.S. DOE have enacted various regulations to encourage school districts to allocate funding equitably across schools. Below I provide some background on federal funding regulation and discuss the changes made through ESSA. I then present summary statistics for variables that measure "teacher resources" (average teacher salary spending per student, teacher experience, and teacher-student ratios) across schools.

\section{Policy Regulations in Title I and Changes under ESSA}

Following the passage of ESSA, the DOE conducted the process of "negotiated rulemaking," in which the Department writes the rules for how a law will be implemented and constituencies affected by a law are nominated and convene to provide input into specific regulations. Historically, the government ensured federal Title I funding reaches the intended students through three requirements: (a) maintenance of effort; (b) comparability; and (c)

\footnotetext{
${ }^{3}$ As with other branches of the government, the DOE must go through a process of "negotiated rulemaking," in which the constituencies affected by a law are nominated and convene to provide input into specific regulations for how a law will be implemented. The final ESSA regulations approved under the Obama administration appeared in the Federal Register on December 8, 2016 (Vol. 81, No. 236). The DOE provided responses to comments on the initially proposed regulations in a longer document posted to their website (https://ed.gov/policy/elsec/leg/essa/essaaccountstplans1129.pdf=).
} 
supplement, not supplant. ${ }^{4}$ Maintenance of effort implies that no states or districts can decrease total or per-pupil funding by more than $10 \%$ from the prior year. ESSA makes no major changes to the maintenance of effort requirement.

Comparability requires districts to staff Title I schools with equal to or more instructional staff per pupil compared to non-Title I schools (the "Comparability Rule"). This policy is meant to ensure that districts will allocate funding equitably across schools. However, in many cases, the highest-poverty schools within districts have, on average, the least experienced teaching staff (Goldhaber et al., 2015). Because districts typically use standardized salary schedules that offer higher compensation to more experienced teachers, districts that use equal staffing ratios across schools often allocate less teacher salary funding per student to the highest-poverty schools. The "comparability loophole" refers to the lack of any requirement that districts spend equal dollars per student across schools (Hanna, Marchitello, \& Brown, 2015; McClure, 2008; National School Board Association, 2013; Roza, 2008; Roza, Miller \& Hill, 2008). While the DOE has used the enactment of ESSA to push for equalized spending on teacher salaries across schools, ESSA makes no changes to the statutory language of the comparability requirement and the DOE did not suggest changes to the methods in which districts meet the comparability requirement. Instead, the DOE pushed for equalized spending on teachers in their initial "Notice of Proposed Rulemaking" (published May 31, 2016) through the supplement, not supplant (SNS) requirement (Gordon, 2016). Under SNS, federal dollars may not be used for purposes that state law already requires schools to spend money on - federal dollars must supplement, not supplant,

\footnotetext{
${ }^{4}$ These three regulations are outlined, respectively, in ESEA Sections 1118(a) and 8521, as amended by the ESSA; $\S \S 20$ U.S.C. 6321(a), 7901, ESEA Section 1118(b); §§20 U.S.C. 6321(b), and ESEA Section 1118(b); §§20 U.S.C. 6321(c).
} 
state and local dollars. ${ }^{5}$ The SNS regulation is substantially changed under ESSA. The new law allows states and districts to design their own methodology to determine whether the SNS requirement is met. The goal of this change is to remove the burdensome reporting requirements under SNS, while maintaining some degree of accountability. Following substantial opposition from members of congress and local stakeholders (Gordon \& Reber, 2015), the DOE elected not to require equal spending across schools in its Final Regulations (DOE, 2016). ${ }^{6}$ However, as part of the plans for state accountability (Section 200.21 of ESSA), the DOE required districts undergoing state accountability-based improvement plans to "address resource inequities," including "disproportionate assignment of ineffective, out-of-field, or inexperienced teachers and possible inequities related to the per-pupil expenditures" (p. 293, DOE, 2016). In March 2017, Congress employed the rarely used Congressional Review Act to block all of the previously established regulations for implementing ESSA. Later that month, the DOE released a revised set of rules that excludes any regulations of district teacher resource gaps described above.

In summary, in an effort to close the "comparability loophole," the DOE initially used changes to the supplement-not-supplant requirement to mandate that districts demonstrate equal

\footnotetext{
${ }^{5}$ Determining how districts would fund schools in the absence of Title I is not straightforward. In previous iterations of the federal education law (ESEA, later reauthorized as the No Child Left Behind Act), schools demonstrated compliance with SNS by reporting, on a cost-by-cost basis, what was purchased with Title I funds. Past research has shown that because funds allocated to the core instructional program are difficult to justify as "extra" or supplemental, most schools choose instead to use Title I funding for external programs (Gordon, 2016). The result is that schools create fragmented budgets that allocate Title I funding to ineffective add-on programs or special pullout programs that remove high-needs students from the mainstream curriculum (Gordon \& Reber, 2015). ${ }^{6}$ The second change to Title I funding regulation in ESSA relates to the schoolwide provision. Under the No Child Left Behind Act, schools could use Title I funding for schoolwide purposes if at least $40 \%$ of students qualified as low-income. Schools receiving Title I funding that did not have more than $40 \%$ of students qualify for funding were required to spend the funding specifically on academically struggling students. Schools could target funding by providing those students with, for example, smaller class sizes, after school programs, targeted professional development for their teachers, or some other targeted intervention. ESSA permits states to apply for waivers that would allow schools to use Title I funding on schoolwide purposes, regardless of whether those schools met the $40 \%$ threshold. While this change is noteworthy, the analyses described in this article do not specifically address changes to the schoolwide versus targeted assistance programs of Title I.
} 
spending across schools. In their Final Regulations, the DOE removed this requirement, but included regulations under state accountability plans that would force districts with lowerperforming schools to address funding disparities and teacher experience gaps across schools. Finally, under Secretary DeVos, the Department released a new set of regulations for ESSA that excludes any intra-district funding regulations, thereby placing greater responsibility on state education agencies to resolve existing funding disparities.

\section{Variation in Teacher Resources}

On average, elementary schools spend $\$ 3,176$ per student on teacher salaries with state and local funds, staff schools with 5.7 teachers for each 100 students, and have about $81 \%$ of teachers with three or more years of experience. These values are shown in Table 1. Variables are reported such that larger numbers reflect a greater level of resources (5.7 teachers per 100 students equates to 17.5 students per teacher). The interquartile range for elementary schools shows, for example, that the bottom quartile of schools have fewer than $77 \%$ of teachers with three or more years of experience, whereas the highest quartile of schools has at least $90 \%$ experienced teachers (i.e., an interquartile range of $10 \%$ to $23 \%$ novice teachers).

The third row within each cell shows intraclass correlations, which measure the extent to which observations are correlated within states. Whether there is variation in teacher resource variables and the level at which this variation exists (i.e., state, district, school) has implications for the assessment of teacher resource gaps. The higher the intraclass correlation, the more states differ in their overall average level of instructional resources available to students. For elementary schools, $54.6 \%$ of the variation in per-pupil teacher salary expenditures is across states (and $45.4 \%$ is within states). These figures align with prior research showing much of the differences in district per-pupil expenditures are across states (Card \& Payne, 2002). In contrast, 
the average percent of experienced teachers in each school is less clustered within states, implying that the average teacher experience in a particular school is relatively similar across states. The average teacher experience at a student's school depends more on which district and school the student attends in any given state, rather than the particular state in which the student attends school. In the section below, I describe the methods used to address our research questions.

\section{Data and Analytic Approach}

\section{Data and Sample}

The study draws on new school-level expenditure data collected by the Office of Civil Rights for the 2013-14 school year. These data are linked to school-level data from NCES, district-level data from the U.S. Census Bureau, and the district-level Education Comparable Wage Index (Taylor \& Fowler, 2006). NCES data include information on student demographics, the school's Title I status, district urbanicity, and enrollment size. U.S. Census Bureau data provide information on school district revenues, expenditures, and poverty rates.

The Office of Civil Rights received teacher expenditure data from 86,802 schools. Importantly, districts reported actual teacher salary expenditures in each school, based on the actual salaries earned by teachers in those schools (rather than simply costing teacher salary expenditures based on average district salaries. I omit from the sample schools with missing student demographic data and schools that reported inaccurate teacher salary or other resource data (for example, reporting greater teacher salary expenditures than district expenditures). The final analytic sample includes 14,447 districts and 81,424 schools, representing $89.7 \%$ of all currently operational, non-virtual, and non-state-operated campuses listed in NCES data. 
Measuring within-district teacher resource gaps. I define teacher resource gaps as the difference in three measures of average teacher resources between schools with high- and lowproportions of students of color and in poverty. Measures of teacher resources include the (a) per-student teacher salary expenditures from state and local funding, (b) the number of teachers for each 100 students, and (c) the percent of teachers with three or more years of experience at the school (shown in Table 1). I begin by predicting the first measure of teacher resources, expenditures on teacher salaries per student (labeled $T R_{s d}$ ), based on the percent of students eligible for FRL (labeled \% $\left.F R L_{s d}\right)$ :

$$
\begin{aligned}
T R_{s d}=\beta_{0} & +\beta_{1} \% F R L_{s d}+\beta_{2} M S_{s d}+\beta_{3} H S_{s d}+\beta_{4} \text { Other }_{s d}+\beta_{5} \% F R L^{*} M S_{s d} \\
& +\beta_{6} \% F R L^{*} H S_{s d}+\beta_{7} \% F R L^{*} \text { Other }_{s d}+\varphi_{d}+\mu_{s d}
\end{aligned}
$$

Equation 1 includes dummy variables for whether school $s$ in district $d$ is a middle school $\left(M S_{s d}\right)$, a high school $\left(H S_{s d}\right)$, or a span / non-graded school $\left(\right.$ Other $\left._{s d}\right)$. The model includes district fixed effects, labeled $\varphi_{d}$, which allow for within-district comparisons ( $\mu_{s d}$ is the residual and standard errors are clustered at the district level). Thus the $\beta_{1}$ coefficient provides an estimate of the change in per-pupil teacher salary spending in elementary schools for a $100 \%$ increase in the percent of FRL students. The coefficients for the middle and high school interaction terms, $\left(\beta_{5}\right.$ and $\beta_{6}$ ), show whether the relationship between funding and school poverty rate differs for middle and high schools (compared to elementary schools).

Next, I substitute the outcome measure, per-pupil teacher salary spending, with the ratio of teachers for each 100 students and the percent of teachers with three or more years of experience. Finally, I re-run each of the models this time exchanging \% FRL with the percent of students at each school who identify as an underrepresented minority. For each set of models, I begin with a null model that includes only the variable of interest (\%FRL, \%URM, or Title I 
school indicator), then add district and state covariates, state fixed effects, and finally, the preferred model which includes district fixed effects (equation 1). This approach makes it possible to examine explicitly the presence of teacher resource gaps both across and within school districts.

I also examine teacher resource gaps by creating direct measures of within-district resource gaps. To construct these variables, I first measure the average teacher salary expenditures per student, average number of teachers for each 100 students, and average percent of teachers with more than two years of experience, in the highest and lowest poverty quartiles of elementary schools within each district (as measured by the percent FRL at each school). I construct the same measures for elementary schools at the highest and lowest quartiles of percent of student of color, and create each of these measures separately for middle and high schools. In order to accurately measure upper and lower quartiles of student demographic variables, I exclude districts with fewer than four elementary schools for analyses of elementary school teacher resource gaps and make similar sample restrictions for analyses of teacher resource gaps in middle and high schools.

\section{Assessing district characteristics associated with teacher resource gaps. For the} second research question, I fit models predicting district-level teacher resource gaps, based on state and district characteristics. Models are run separately for teacher resource gaps across elementary, middle, and high schools (using the constructed measures of teacher resource gaps described above). I run a series of ordinary least squares regressions predicting teacher resource gaps, beginning with district covariates. The primary variables of interest are district-level perstudent state and local funding, expenditures, and teacher salaries (I include these variables in separate models since they are highly correlated). Other district covariates include factors 
affecting the cost of education: district poverty rate, district enrollment size, urbanicity, and the educational cost of wage index (Taylor \& Fowler, 2006). I also control for student segregation, using a constructed measure of economic and racial segregation (the difference between the top and bottom quartile of schools in the \% FRL or percent of underrepresented minority students, URM), as well as average teacher experience. I then add state covariates, state fixed effects (removing the state covariates), and finally, county fixed effects. As before, I run identical models examining teacher resource gaps based on \% FRL and \% URM students at the school. Models with county fixed effects allow for focusing on differences in resources levels between districts in the same labor market.

As a secondary approach for addressing research question two, I also run school-level models similar to equation 1 , this time adding interactions between district funding levels and the $\%$ FRL and (in separate models) URM students. I include the same set of district covariates as before. For these models, each teacher resource variable is mean-centered within districts to focus on within-district disparities across schools. Because I control for district characteristics related to the cost of education, the coefficient for the interaction between per-pupil funding and the percent of students at the school eligible for FRL shows whether increases in per-pupil funding are associated with more equitable teacher resource allocation. Finally, to make these results more interpretable, I estimate predicted values of teacher resources across school-level percent FRL and percent URM, calculated at various levels of district per-pupil funding. ${ }^{7}$

\section{Findings}

\footnotetext{
${ }^{7}$ For these models, I convert state and local per-pupil funding to a percentage difference from the statewide mean. A value of 0.1 implies a particular district receives $10 \%$ more funding than the state average. Predicted values are estimated using the margins command in STATA.
} 
Results are presented in three sections. I first review findings for the first research question on the extent to which teacher resources are equitably distributed. Section two provides results for the second research question of what factors are associated with teacher resource gaps. Finally, I discuss some extensions and specification checks to support these findings.

\section{Assessing Teacher Resource Gaps}

Results for research question 1 are shown in Tables 3 and 4. Panel A of Table 3 shows results for per-student teacher salary expenditures, Panel B shows teacher-pupil ratios, and in Panel C I report findings for teacher experience. As shown in the first row of column 1, on average nationally, elementary schools receive \$9.59 less per student in state and local funding for teacher salaries for each 1\% increase in FRL students, equivalent to a \$959 per-pupil gap between schools with 100\% FRL and 0\% FRL. That number reduces to about \$264 when comparing schools in the same state and controlling for local district cost factors (shown in column 3). Log models indicate an $11.1 \%$ gap between 0\% FRL schools and 100\% FRL schools in the same state. ${ }^{8}$ Funding for middle schools is even more inequitable, whereas funding for high schools is slightly more equitable compared to elementary schools (rows 2 and 3). The final column of Table 3 shows results for models that include district fixed effects, which allow for comparisons of schools within the same district. The relationship between poverty rates and teacher expenditures reverses when comparing schools in the same district - higher poverty schools receive more funding for teacher salaries, on average, than lower-poverty schools in the same district (about \$272 more per student between 0\% FRL schools and 100\% FRL schools in the same district, or about $6.3 \%$ based on log models). Results for teacher-pupil ratios follow a similar pattern (Panel B). Results are similar for students who identify as an underrepresented

\footnotetext{
${ }^{8}$ All log models are available from the author upon request.
} 
minority and in comparisons between Title I and non-Title I schools (results shown in online appendix Table A1). These findings suggest that on average, the disparities observed in models 1-3 result primarily from inequitable funding across states and across districts within states, not from inequities within districts, as several studies have suggested (e.g., Roza \& Hill, 2004).

In contrast, teacher experience gaps exist both across schools in the same state and across schools in the same district. The coefficient for elementary schools of - 0.079 in the first row of Panel C, Column 4 (of Table 2) suggests that, comparing schools in the same district, a 100\% increase in the percent of FRL students is associated with a 7.9 percentage point decrease in the proportion of teachers with three or more years of experience. Elementary schools with $75 \%$ FRL students have, on average, $79.8 \%$ of teachers with three or more years of experience (after adjusting for covariates), whereas lower-poverty elementary schools with 25\% FRL have 83.8\% of teachers with three or more years of experience on average, a gap of about 4.0 percentage points. As demonstrated by the coefficients for middle and high schools in Column 4 of Panel C, experience gaps in middle and high schools are even greater. Based on the predicted values, the within-district experience gaps for middle and high schools are 6.5 and 6.1 percentage points, respectively (based on comparisons between schools with 25\% FRL and 75\% FRL in the same district). Teacher experience gaps are even greater for students of color (see appendix Table A2). These findings comport with other statewide analyses of teacher attrition (e.g., Hanushek et al., 2004; Goldhaber et al., 2015) - low-income students and students of color disproportionately attend schools with the least experienced teachers within school districts.

Given that districts actually spend more per student on teacher salaries in their higher poverty schools by providing more teachers per student, a natural question is whether districts are encouraged to do so through the federal Comparability Rule. I address this question by 
comparing resource allocation patterns in districts with at least one, but not all Title I schools to districts with all Title I schools. Because the Comparability Rule regulates resource allocation between Title I and non-Title schools, districts with all Title I schools are not affected by the Comparability Rule. Results described above are not substantially different when running analyses separately for districts with at least one, but not all Title I schools and for districts with all Title I schools (shown in online appendix Table A2). ${ }^{9}$ That districts with all Title I schools provide more teachers per student in their high-poverty schools suggests that on average, districts use equal or progressive staffing ratios across schools even when not mandated to do so through the federal Comparability Rule (which only regulates staffing ratios between Title I and nonTitle I schools).

Table 3 shows similar results based on the constructed measures of within-district teacher resource gaps (positive gaps represent inequitable distributions). The figures align with the findings reviewed above: On average, high-poverty elementary schools receive slightly more teacher salary funding per student (about $\$ 36$ for elementary schools or 5.3\% of a standard deviation), and have more teachers per student than low-poverty schools in the same district, while teacher experience is inequitably distributed within districts. ${ }^{10}$ Although the teacher salary

\footnotetext{
${ }^{9}$ Specifically, the coefficient for \% FRL on models predicting per-student teacher salary spending is 273.1 for districts with at least one, but not all Title I schools and 339.3 for districts with all Title I schools (a difference of 66.2 which is not statistically significant). Similarly, the coefficients for teachers per pupil for each group is 0.978 and 0.789 , respectively, and for models predicting teacher experience, 0.078 and 0.075 , respectively. As noted in Table 1, only 531 districts have zero Title I schools, representing 880 schools and $0.7 \%$ of all students. Because these districts have relatively small (with an average of 1.7 schools per district), I do not make comparisons between high- and low-poverty schools within these districts.

${ }^{10}$ Results for middle schools change slightly when the sample is limited to districts with at least four middle schools. As shown in Table 2, Model 4 (which includes district fixed effects), across the full sample, elementary and high schools have slightly more equitable funding that middle schools (although districts allocate greater per-student teacher salary funding to higher-poverty schools at all three school levels). However, when the sample is limited to districts with at least four elementary, middle, or high schools, middle and high schools are slightly more equitable funding distributions than elementary schools (and, as before, teacher salary funding is equitably distributed at all three school levels). Appendix Table A4 shows regression coefficients for models that limit the sample to districts with at least four elementary, middle, or high schools.
} 
gap for \% URM in elementary schools is positive (\$21), this figure is only $2.8 \%$ of a standard deviation in the overall salary spending gap for \% URM in elementary schools. Thus, the withindistrict teacher salary gap in elementary schools for both \% FRL and \% URM is very close to zero. The intraclass correlations for teacher resource gaps are substantially smaller than for teacher resources. Between $91 \%$ and $99 \%$ of the variation in teacher resource gaps is within states (teacher resource gaps are more related to which district a student attends within a given state and less related to the state in which a student lives). This suggests that states do not differ substantially in their average teacher resource gaps, and it may be less likely that state policies would explain much of the variation in teacher resource gaps. At the same time, states may have policies that differentially impact districts, so a lack of substantial differences across state average resource gaps does not necessarily imply that state policy does not serve an important role. In the section below, I examine variation in teacher resource gaps and whether district or state characteristics are associated with those gaps.

Next, Figure 1 plots results for teacher resource gaps based on the proportion of lowincome students in elementary schools. The x-axis for the graph on the left shows average teacher salary expenditures per student in elementary schools that serve the highest-income students within their districts and the y-axis shows average teacher salary expenditures in elementary schools that serve the lowest-income students within their districts. Districts that fall above the dotted line have more equitable allocation of teacher salary expenditures in that higher poverty schools receive more salary expenditures per student. The graph on the right presents the same information for teacher experience (the average percent of teachers with two or fewer years of experience). The graphs illustrate that although districts allocate more funding per student for teacher salaries to their high-poverty schools, on average, many districts have inequitable 
distributions. Similarly, while teacher experience is inequitably distributed across schools within districts, many districts have more experienced teachers in their highest-poverty schools. I next describe results of models that examine variation in teacher resource gaps more closely.

\section{Factors Predicting Teacher Resource Gaps}

Tables 4 shows regression coefficients predicting teacher resource gaps based on districts characteristics (all models are district-level regressions). The first column includes state and district covariates and the second and third columns replace state covariates with state fixed effects and then county fixed effects. Columns 1-3 examine income-based teacher resource gaps and columns 4-6 repeat the same regressions for teacher resource gaps based on race/ethnicity. Districts that receive higher state and local funding per student have lower income-based teacher resource gaps than otherwise similar districts in the same state or county. The coefficient in the first row of column 2 suggests that for each additional $\$ 1,000$ of state and local funding per student relative to other districts in the same state (about $19 \%$ of a standard deviation across all districts nationally), the within-district gap in per-pupil teacher salary spending reduces by $\$ 29$, or about $4.3 \%$ of a standard deviation. Models with county fixed effects (column 3, comparing districts in the same county) suggest the same increase in funding would lower teacher salary gaps within districts by $\$ 21$ (3.1\% of a standard deviation). Log models show that a $10 \%$ in funding relative to other districts in the same county reduces the teacher salary gap by $0.5 \%$. Results are consistent when I substitute the average state and local per-pupil funding with (a) the district average per-pupil teacher salary spending or (b) overall expenditures per student (run separately). ${ }^{11}$

\footnotetext{
${ }^{11}$ These results are not shown, but are available from the author upon request. I find that a $\$ 1,000$ increase in district per-pupil expenditures is associated with a reduction of $4.6 \%$ of a standard deviation of the teacher salary spending gap when comparing districts in the same state (i.e., state fixed effects) and a $4.3 \%$ reduction when comparing districts in the same county (county fixed effects). A \$1,000 increase in the district average per-pupil teacher salaries
} 
The same increase in state and local funding lowers the gap in teacher-student ratios by 0.025 teachers per 100 students when comparing districts in the same state and by 0.029 when comparing districts in the same county (i.e., county fixed effects, column 3 of Panel B). As shown in Panel C of Table 4, a \$1,000 increase in state and local funding is associated with a 0.4 percentage point reduction in the teacher experience gap when comparing districts in the same state (model 2) and a 0.6 percentage point reduction when comparing districts in the same county (model 3). Given the standard deviation of the income-based teacher experience gap of 9.2 percentage points (shown in Table 3), these coefficients equate to a reduction of $4.4 \%$ and $6.5 \%$ of a standard deviation, respectively. Log models show that a $10 \%$ increase in funding relative to other districts in the same county reduces the teacher experience gap by $1.3 \%$. When I substitute state and local funding per student with the district average teacher salary expenditures per student and overall expenditures per student, coefficients are still negative, but not significant. Finally, the results shown in columns 4-6 suggest that results are similar for teacher salary spending and teacher-student ratios when examining teacher resource gaps based on race/ethnicity, but are small and statistically insignificant for teacher experience gaps.

Several other district characteristics have statistically significant relationships with teacher resource gaps. Not surprisingly, economic and racial segregation are associated with economic and racial teacher resource gaps, but the direction of the relationship varies by resource. Columns 1-3 of Table 3 show that as the level of economic segregation increases, districts provide even smaller class sizes in their highest-poverty schools (more students per teacher), but have larger teacher experience gaps. Economic segregation is not related to gaps in teacher salary spending. The same trend holds for segregation by race/ethnicity. Racial 
segregation is unrelated to teacher salary spending after adding state fixed effects, perhaps because of the way class sizes and teacher experience are distributed in more segregated districts. As racial segregation increases, districts provide even more teachers per student in their highest minority schools, but exhibit larger teacher experience gaps.

The third row within in panel of Table 3 shows coefficients for district poverty level. Higher-poverty districts have larger gaps in teacher salary and teacher-student ratios, compared to otherwise similar lower-poverty districts in the same state or county, but poverty rate is not related to teacher experience gaps. ${ }^{12}$ This finding contradicts those reported in Goldhaber et al. (2015), which found greatest teacher experience gaps in higher-poverty districts. However, I ran identical models for just Washington State (the setting of the Goldhaber et al. study) and confirmed that in Washington, district poverty rate is positively correlated with teacher experience gaps, whereas that relationship reverses, on average, for the rest of the country. Urban districts have larger teacher experience gaps than otherwise similar suburban and rural districts in the same state, while district enrollment is generally unrelated to teacher resource gaps. Compared to districts in the same state, both teacher-student ratio gaps and teacher experience gaps increase with the cost of wage index. Finally, the average percent of experienced teachers across all schools in a district is associated with both lower teacher salary expenditure gaps and lower teacher experience gaps. This finding likely suggests that districts with higher attrition are more likely to have larger teacher experience gaps compared to otherwise similar districts in the same state or county with lower attrition.

\footnotetext{
${ }^{12}$ I also ran the models described in equation 1 (predicting teacher resources based on student demographics) separately for high-poverty districts (above the 75th percentile within the state), mid-poverty districts (25th to 75 th percentile of poverty within the state) and low-poverty districts (below the 25 th percentile of district poverty rate). As expected, the coefficient for \% FRL in models predicting both teacher salaries per student and teacher-student ratios is largest in low-poverty schools, but positive for all three. In contrast, the \% FRL coefficient in models predicting teacher experience is negative across the poverty distribution, but teacher experience is the least inequitably distributed in high-poverty districts (and most inequitably distributed in mid-poverty districts).
} 
Finally, Figure 2 shows how per-pupil funding is associated with the extent to which districts target greater teacher resources to their highest-poverty schools. The graphs plot the relationship between \% FRL and the amount of (a) teacher salary expenditures per student, (b) teacher-student ratios, and (c) average percent of experienced teachers, for districts that receive $15 \%$ less funding than their state average (after controlling for observable differences in cost) and for districts that receive $15 \%$ more funding than their state average. As described earlier, the average district allocates slightly more teacher salary funding per student in their higher poverty schools. However, the first graph of Figure 2 shows that districts with greater funding levels allocate teacher salary expenditures even more progressively with respect to school poverty rate, whereas districts receiving less state and local funding allocate teacher salary expenditures regressively (as indicated by the downward sloping dashed line in the graph on the left).

The next two graphs of Figure 2 provide evidence for why this relationship exists. The middle graph shows that districts staff their higher-poverty schools with more teachers per student on average, but that relationship becomes stronger as district funding increases. Similarly, the graph on the right shows that teacher experience is inequitably distributed within school districts, on average, but this relationship weakens with increases in district funding. That is, greater district funding is associated with more equitable distributions of teacher experience within school districts. Regression coefficients from these models show that the differences in the slopes of these lines are significant at conventional levels. ${ }^{13}$

\section{Specification Checks and Extensions}

The primary finding that per-pupil funding is associated with lower teacher resource gaps could result from a variety of reasons. Above, I argued that more resources help districts

\footnotetext{
13 The coefficients for the interaction between per-pupil funding and the percent of students at the school eligible for FRL are significant for all three teacher resource variables.
} 
maintain supportive working conditions in their higher-need schools. Alternatively, districts that receive more funding may differ in some other way that is correlated with both district funding and lower teacher resource gaps. For example, districts with greater funding levels, relative to other districts in the same state or county, might be located in more advantaged neighborhoods. If districts in more advantaged neighborhoods attract a teaching workforce with greater preference for working in the least advantaged schools within those districts, then changes in funding rates would not alter teacher resource gaps, since the underlying causal mechanism would be a third variable that is only correlated with funding rates and resource gaps.

One way to examine the possibility of omitted variable bias is by estimating the biasadjusted treatment effect as proposed by Oster (Forthcoming). This procedure compares changes in the coefficient of interest to changes in the r-squared between the null model (with no covariates) to the full model (with all covariates). ${ }^{14}$ In each of the results shown in Table 4 adding covariates increases the r-squared substantially, suggesting that observable characteristics explain much of the variation in teacher resource gaps. Moreover, in each case (with the exception of the model predicting race/ethnicity teacher experience gaps), the coefficient for perpupil funding increases as additional covariates are added (the null model with no covariates is not shown). The bias-adjusted treatment effect is therefore larger than the main effect for each of the results shown in Table 4.

Given that the sample is limited to districts with at least four elementary schools (for analyses of elementary teacher resource gaps), some of the fixed effects estimates may not draw

\footnotetext{
${ }^{14}$ Specifically, the bias-adjusted treatment effect is $\beta_{\text {full }}-\delta *\left(\beta_{\text {null }}-\beta_{\text {full }}\right) *\left[\left(\mathrm{R}_{\max }-\mathrm{R}_{\text {full }}\right) /\left(\mathrm{R}_{\text {full }}-\mathrm{R}_{\text {null }}\right)\right]$, where $R_{\max }$ is the expected r-squared if all observable and unobservable covariates were included (assumed to be 1 ), $\delta$ is the proportion of selection bias due to observable versus unobservable factors, and the subscripts full and null refer to the $\beta$ and r-squared for the full model, with all covariates and the null model, with no covariates (Oster, Forthcoming).
} 
on a sufficient number of districts within states or counties, potentially limiting the ability to observe within-state or within-county comparisons. However, results are consistent when I limit the sample to states with at least 40 districts that meet sample requirement. Results from county fixed effects are also consistent when I limit the sample to only counties with at least 10 districts. The coefficient for per-pupil funding in county fixed effects models that predict teacher experience gaps increases to 0.008 when the sample is limited to counties with at least 10 districts, implying that each additional $\$ 1,000$ per student relative to districts in the same county is associated with a reduction in the teacher experience gap of $8.7 \%$ of a standard deviation.

A second specification test examines the sensitivity of the results to the measurement of teacher resource gaps. To do this I created a second set of teacher resource measures that compare the difference between teacher resources in schools that fall in the top half of \% FRL and \% URM and those that fall in the bottom half (rather than the top and bottom quartile). As before, I make these calculations separately for elementary, middle, and high schools. This approach makes it possible to include districts with only two elementary schools (and for analyses of middle and high schools, districts with only two of those school types). Results are similar when using this alternate measure, although in some cases, the magnitude of the coefficient for per-pupil funding decreases slightly.

Finally, I extend the analysis by exploring potential underlying mechanism to explain the relationship between district funding and within-district resource allocation equity. I examine a series of interaction effects between per-pupil funding and district characteristics for models predicting teacher resource gaps. Models with interactions between measures of segregation and district funding suggest that district per-pupil funding has a stronger relationship with narrowing of teacher resource gaps in more segregated districts. District-level resources may thus be even 
more important for closing teacher resource gaps in districts that have more segregation across schools. However, poverty rate, district percent of student of color, urbanicity, and district size are all unrelated to the relationship between funding and teacher resource gaps (interactions are all insignificant). In other words, resources appear equally as important in closing teacher resource gaps regardless of district poverty, student demographics, urbanicity, and enrollment size.

\section{Discussion}

This study contributes to understanding of educational inequality in a number of ways. Consistent with prior analyses (e.g., Card \& Payne, 2002), results show that inequality in school resource allocation is primarily caused by disparities across states and across districts within states, while funding is slightly more evenly distributed within school districts on average. This pattern holds regardless of whether districts face federal regulation through the Comparability Rule, suggesting that districts likely have alternate incentives to allocate resources equitably across schools beyond compliance with federal policy. For example, given studies that show lower-achieving and lower-income students benefit more from additional resources that provide, for example, lower class sizes or other programs that may improve teacher retention (Ronfeldt, Loeb \& Wyckoff, 2014), district leaders may choose to target more resources to higher need schools. Additionally, many states regulate district resource allocation across schools (Picus \& Odden, 2015).

I also find that despite district efforts to equalize learning opportunities by providing equitable funding across schools, novice teachers are clustered in higher-poverty and higherminority schools within districts nationally. While districts typically have direct control over class size and teacher-pupil ratio policies - and most staff higher-poverty schools with more 
teachers per student - districts have far less control over the distribution of teacher experience (Darling-Hammond, 2004; Loeb \& Strunk, 2007). As a result, districts allocate more funding to their higher-poverty schools by lowering class sizes, rather than having more experienced teachers in those schools. At the same time, these broad averages mask substantial variation in teacher resource gaps. Many districts actually provide less funding per student for teacher salaries in schools with the highest percent of low-income students and student of color, while other districts have equal to or more experienced teachers in their highest need schools. In contrast to teacher resources, most of the variation in teacher resource gaps is across districts in the same state.

Finally, district inputs may explain some of the variation in the distribution of teacher resources. Results for the second research question show that holding constant local cost factors, districts that receive more funding per student, spend more, or offer higher salaries, relative to other districts in the same state or county, have lower teacher salary expenditure gaps, lower teacher-pupil ratio gaps, and in most cases, lower teacher experience gaps. In districts that receive greater funding per student relative to otherwise similar districts in the same state or county, teacher experience is more equitably distributed across high- and low-poverty schools. Second, in part by definition, less segregated districts have more equitable distributions of teacher resources. In short, additional resources and less segregated schools both appear to help districts allocate funding more equitably and close teacher experience gaps.

These findings have important policy implications. First, the DOE's requirement that lower-performing districts, as determined by state accountability plans, address across-school resource inequities would likely affect a substantial number of school districts. Many districts already allocate teacher salary expenditures equitably across schools. However, consider the 
simple difference in funding between Title I and non-Title I schools. The data show that approximately 939 districts provide more teacher salary expenditures per student to non-Title I elementary schools, compared to their Title I elementary schools (46\% of the 2,030 districts with at least one Title I elementary school and at least one non-Title I elementary school). A total of 7.0 million students attend Title I elementary, middle, or high schools in districts where nonTitle I schools receive more per-pupil teacher salary funding, on average, than Title I schools at the same grade level. The total expenditure required to equalize average funding in Title I schools to that of non-Title I schools across all districts nationally is $\$ 3.3$ billion (a $2.2 \%$ increase in total state and local teacher salary spending nationally). Given standardized teacher salary schedules, districts would most likely accomplish this by increasing teacher-student ratios in Title I schools. Without additional revenues however, districts would need to implement forced teacher placements, which prior research shows are largely unpopular and ineffective (Miller \& Lee, 2014).

The findings suggest that districts' ability to close teacher resource gaps likely depends, in part, on the availability of resources, relative to observationally similar districts in the same state or county. Policies that provide more resources for underfunded school districts may help those districts narrow teacher quality gaps. Thus federal efforts to provide more equitable access to high-quality teachers may benefit from placing additional pressure on state school finance systems. The federal government has exhibited substantial influence on state education agencies through competitive grants (i.e., Race to the Top) and waivers from federal policies (Wrabel, Saultz, Polikoff, McEachin \& Duque, 2016). The DOE has little direct influence over state legislatures, which control school district funding levels. Most of the external pressure placed on state legislatures to alter school funding has historically come through state and federal judicial 
decisions. The federal government's focus on state education agencies and district human capital policies may simply be a response to lack of authority over state legislatures. However, identifying incentives for state legislatures to increase the equity and overall level of funding across districts, perhaps by expanding Title I funding through the Education Finance Incentive Grants (which currently comprise $23 \%$ of Title I funding) may be an effective approach to improving equitable access to high-quality teachers within districts.

A second policy implication relates to understanding of the teacher labor market and school district achievement gaps. Despite recent efforts to understand the extent to which disadvantaged students have equitable access to experienced teachers, federal and state policymakers have little knowledge of the types of districts with larger teacher experience gaps. This gap in the literature is especially important given recent findings showing that district-level achievement gaps persist across the income distribution, in low-, middle- and higher-income districts nationally (Reardon, Kalogrides, \& Shores, 2016). The findings from this study contradict prior statewide analyses in Washington and North Carolina, which found that higherpoverty districts have wider teacher experience gaps (Goldhaber et al., 2015; Clotfelter et al., 2005). I find that while experience gaps exist across the distribution of district poverty rates, teacher experience gaps are actually the smallest in the highest-poverty districts and largest in mid-poverty districts. Teachers who choose to work in high-poverty districts may also choose to work (and remain) in their district's highest-poverty schools. The propensity for greater teacher retention in the highest poverty schools of high-poverty districts (compared to the highestpoverty schools of low-poverty districts) could be seen as an untapped asset for high-poverty districts that are struggling with teacher retention. In summary, the problem of inequitable access to experienced teachers is not limited to, or even concentrated in, high-poverty districts. 
Third, the study has implications related to efforts to address educational inequality more broadly. Much of the recent policy debates surrounding the inequitable access to effective teachers has centered on state laws related to teacher tenure, transfer, and dismissal (for example, Vergara v. California, Wright v. New York, and others). The role of equitable and adequate resources across school districts is notably absent from the discourse. This study demonstrates the importance of district funding rates, especially relative to otherwise similar districts in the same state or county, in helping districts close teacher experience gaps. Although other factors related to human capital management policies play a role to be sure, district administrators' ability to provide students with equitable learning opportunities across schools depends on their ability to improve teaching and learning conditions in their highest-need schools, which likely requires a sufficient level of resources. Although money is not a panacea for improving working conditions, sufficient resources may be a necessary condition (Grubb, 2009).

Finally, the study adds to policy discussion related to the growing trend of re-segregation across schools by race/ethnicity and by family income levels (Frankenberg \& Kotok, 2013). The national teacher experience gap found in this study adds to the potential problems associated with race- and income-based re-segregation. In addition to increasing of students' interactions with peers from other racial/ethnic or cultural background, desegregation necessarily reduces disparities gaps in resources across schools (Mickelson \& Nkomo, 2012; Reardon \& Firebaugh, 2002). Policymakers aiming to narrow resource gaps between rich and poor schools and between schools serving predominantly white students and students of color could focus on desegregating schools in addition to reallocating resources more equitably.

\section{Conclusions}


As the DOE continues the process of negotiated rulemaking, federal policymakers will need to determine whether any federal regulations will govern the supplement-not-supplant rule, or if the methodology for determining compliance will be left up to individual states. The DOE's ultimate goal of providing students with equitable learning opportunities may be undermined by strict requirements placed on districts to equalize funding across schools. States may benefit from using targeted funding for high-need districts as a way to reduce within-district resource gaps. As this study demonstrates, despite the potentially large impacts of the new federal education law, the greatest control over the distribution of educational opportunity most likely rest with state legislatures who determine human capital management policies, school funding levels, funding allocation patterns. 


\section{References}

Anzia, S. F., \& Moe, T. M. (2014). Focusing on fundamentals: A reply to Koski and Horng. Educational Evaluation and Policy Analysis, 36(1), 120-123.

Baker, B. D. (2014). Evaluating the recession's impact on state school finance systems. Education Policy Analysis Archives, 22(91). http://dx.doi.org/10.14507/epaa.v22n91.2014

Baker, B. D. \& Green, P. (2015). Conceptions of equity and adequacy in school finance. In H. F. Ladd and M. E. Goertz (Eds.), Handbook of research in education finance and governance. (pp. 311-332). New York, NY: Routledge.

Baker, B. D., Farrie, D., Johnson, M., Luhm, T., \& Sciarra, D. G. (2017). Is school funding fair? A national report card, sixth edition. Newark, NJ: Education Law Center.

Baker, B. D., \& Corcoran, S. P. (2012). The stealth inequality of school funding: How state and local school finance systems perpeturate inequitable student spending. Washington, DC: Center for American Progress.

Baker, B. D., Taylor, L., Levin, J., Chambers, J., \& Blankenship, C. (2013). Adjusted poverty measures and the distribution of Title I aid: Does Title I really make the rich states richer? Education Finance Policy, 8(3), 394-417.

Baker, B. D., \& Weber, M. (2016). State school finance inequities and the limits of pursuing teacher equity through departmental regulation. Education Policy Analysis Archives, 24(47). http://dx.doi.org/10.14507/epaa.v24.2230

Boyd, D., Grossman, P., Ing., M., Lankford, H., Loeb, S. \& Wyckoff, J. (2011). The influence of school administrators on teacher retention decisions. American Educational Research Journal, 48(2), 303-333. DOI: 10.3102/0002831210380788

Boyd, D., Lankford, H., Loeb, S. \& Wyckoff, J. (2005). The draw of home: How teachers' preferences for proximity disadvantage urban schools. Journal of Policy Analysis and Management, 24(1), 113-132.

Card, D., \& Payne, A. A. (2002). School finance reform, the distribution of school spending, and the distribution of student test scores. Journal of Public Economics, 83(1), 49-82.

Clotfelter, C. T., Ladd, H. F., \& Vigdor, J.L. (2005). Who teaches whom? Race and the distribution of novice teachers. Economics of Education Review, 24, 377-392.

Clotfelter, C. T., Ladd, H. F., Vigdor, J. L., \& Diaz, R. A. (2004). Do school accountability systems make it more difficult for low-performing schools to attract and retain high-quality teachers?. Journal of Policy Analysis and Management, 23(2), 251-271.

Clotfelter, C., Ladd, H. F., Vigdor, J., \& Wheeler, J. (2006). High- poverty schools and the distribution of teachers and principals. North Carolina Law Review, 85, 1345-1379.

Cohen-Vogel, L., Feng, L., \& Osborne-Lampkin, L. T. (2013). Seniority provisions in collective bargaining agreements and the "Teacher Quality Gap". Educational Evaluation and Policy Analysis, 35(3), 324-343.

Darling-Hammond, L. (2004). Inequality and the right to learn: Access to qualified teachers in California's public schools. Teachers College Record, 106(10), 1936-1966.

Darling-Hammond, L. (2000). Teacher quality and student achievement: A review of state policy evidence. Education Policy Analysis Archives, 8(1). Retrieved September 5, 2015 from http://epaa.asu.edu/epaa/v8n1.

Duncombe, W. D. \& Yinger, J., (2004). How much more does a disadvantaged student cost? Working Paper 103. Syracuse, NY: Center for Policy Research. Retrieved December 23, 2015 from http://surface.syr.edu/cpr/103.

Dynarski, M. \& Kainz, K. (2016). Requiring school districts to spend comparable amounts on Title I schools is pushing on a string. Evidence Speaks Reports (Vol 1, \#21). Washington, D.C.: Brookings Institution. 
Eller, W., Doerfler, C., \& Meier, K. (2000). Teacher turnover in Texas: Problems and prospects: A report of the Texas Educational Excellence Project. College Station: Texas Educational Excellence Project.

Frankenberg, E., \& Kotok, S. (2013). Demography and educational politics in the suburban marketplace. Peabody Journal of Education, 88(1), 112-126.

García, O., Kleifgen, J. A., \& Falchi, L. (2008). From English Language Learners to Emergent Bilinguals. Equity Matters. Research Review No. 1. Campaign for Educational Equity, Teachers College, Columbia University.

Goldhaber, D., Quince, V. \& Theobald, R. (2016). Has it always been this way? Tracing the evolution of teacher quality gaps in U.S. public schools. CALDER Working Paper No. 171.

Goldhaber, D., Lavery, L., \& Theobald, R. (2015). Uneven playing field? Assessing the teacher quality gap between advantaged and disadvantaged students. Educational Researcher, 44(5), 293-307.

Gordon, N. (2016, March). Increasing targeting, flexibility, and transparency in Title I of the ESEA. The Hamilton Project.

Gordon, N. \& Reber, S. (2015). The quest for a targeted and effective Title I ESEA: Challenges in designing and implementing fiscal compliance rules. RSF: The Russell Sage Foundation Journal of the Social Sciences, 1(3), 129-147.

Government Accountability Office. (2011, January). Elementary and Secondary Education Act potential effects of changing comparability requirements. Washington, D.C.: Government Accountability Office.

Glazerman, S., \& Max, J. (2011). Do low-income students have equal access to the highestperforming teachers? (No. 6955). Mathematica Policy Research.

Gritz, R. M., \& Theobald, N. D. (1996). The effects of school district spending priorities on length of stay in teaching. Journal of Human Resources, 31(3), 477-512.

Grubb, W. N. (2009). The money myth: School resources, outcomes, and equity. New York, NY: Russell Sage Foundation.

Hanna, R., Marchitello, M., \& Brown, C. (2015). Comparable but unequal: School funding disparities. Washington, D.C.: Center for American Progress. Retrieved from: https://www.americanprogress.org/issues/education/report/2015/03/11/107985/comparabl e-but-unequal/.

Hanushek, E. A. (1997). Assessing the effects of school resources on student performance: An update. Educational Evaluation and Policy Analysis, 19(2), 141-164.

Haxton, C., de los Reyes, I. B., Chambers, J., Levin, J., \& Cruz, L. (2012). A case study of Title I Comparability in three California school districts. Washington, D.C.: American Institutes for Research.

Heuer, R. \& Stullich, S. (2011). Comparability of state and local expenditures among schools within districts: A Report from the Study of School-Level Expenditures U.S. Department of Education Office of Planning, Evaluation and Policy Development Policy and Program Studies Service

Isenberg, E., Max, J., Gleason, P., Potamites, L., Santillano, R., Hock, H., \& Hansen, M. (2013). Access to effective teaching for disadvantaged students. Washington, DC: National Center for Education Evaluation and Regional Assistance, U.S. Department of Education.

Imazeki, J. (2005). Teacher salaries and teacher attrition. Economics of Education Review, 24(4), 431-449. 
Johnson, S. M., Kraft, M. A. \& Papay, J. P. (2012). How context matters in high-need schools: The effects of teachers' working conditions on their professional satisfaction and their students' achievement Teachers College Record, 114, 1-39.

Knight, D. S. (Forthcoming). Are higher-need school districts disproportionately impacted by state funding cuts? School finance equity following the Great Recession. Journal of Education Finance.

Knight, D. S. \& Strunk, K. O. (2016). Who bears the cost of district funding cuts? Equity implications of teacher layoffs. Educational Researcher, 45(7), 395-406.

Krieg, J. M., Theobald, R., \& Goldhaber, D. (2016). A foot in the door: Exploring the role of student teaching assignments in teachers' initial job placements. Educational Evaluation and Policy Analysis, 38(2),364-388.

Ladd, H. F. (2012). Education and poverty: Confronting the evidence. Journal of Policy Analysis and Management, 31(2), 203-227.

Ladd, H. F. (2011). Teachers' perceptions of their working conditions: How predictive of planned and actual teacher movement?. Educational Evaluation and Policy Analysis, $33(2), 235-261$.

Lankford, H., Loeb, S., \& Wyckoff, J. (2002). Teaching sorting and the plight of urban schools: A descriptive analysis. Educational Evaluation and Policy Analysis, 24(1), 37-62.

Leachman, M., Albares, N., Masterson, K. \& Wallace, M. (2016). Most states have cut school funding, and some continue cutting. Washington, D. C.: Center on Budget and Policy Priorities.

Loeb, S., \& Strunk, S. (2007). Accountability and local control: Response to incentives with and without authority over resource generation and allocation. Education Finance and Policy, 2(1), 10-39.

National School Board Association. (2013, June). The challenges and unintended consequences of using expenditures to determine Title I comparability. Retrieved from https://www.nsba.org/sites/default/files/reports/NSBA.pdf

McClure, P. (2008). The history of educational comparability in Title I of the Elementary and Secondary Education Act of 1965. In Ensuring equal opportunity in public education: How local school district funding practices hurt disadvantaged students and what federal policy can do about it. In J. Podesta and C. Brown, (Eds.). (p. 9-31). Washington, D.C.: Center for American Progress.

Mickelson, R.A., \& Nkomo, M. (2012). Integrated schooling, life-course outcomes, and social cohesion in multiethnic democratic societies. Review of Research in Education, 36, $197-$ 238.

Miller, L. J., \& Lee, J. S. (2014). Policy barriers to school improvement: What's real and what's imagined?. Seattle, WA: Center on Reinventing Public Education.

Nye, B., Hedges, L. V. \& Konstantopoulos. S. (2002). Do low-achieving students benefit more from small classes? Evidence from the Tennessee class size experiment. Educational Evaluation and Policy Analysis, 24(3), 201-217.

Office of Civil Rights. (2016, June). 2013-14 Civil Rights Data Collection: A First Look. Washington, D.C.: U.S. Department of Education, Office of Civil Rights.

Oster, E. (Forthcoming). Unobservable selection and coefficient stability: Theory and evidence. Journal of Business \& Economic Statistics.

Peske, H. G. \& Haycock, K. (2006). Teaching inequality: How poor and minority students are shortchanged on teacher quality. Washington, D.C.: The Education Trust. 
Reardon, S.F., Kalogrides, D., \& Shores, K. (2016). The geography of racial/ethnic test score gaps (CEPA Working Paper No.16-10). Retrieved from Stanford Center for Education Policy Analysis: http://cepa.stanford.edu/wp16-10.

Reardon, S. F., Kalogrides, D., Ho, A., Shear, B., Shores, K. \& Fahle, E. (2016). Stanford Education Data Archive. http://purl.stanford.edu/db586ns4974.

Reardon, S. F. (2011). The widening academic achievement gap between the rich and the poor: New evidence and possible explanations. In Duncan, G. J., \& Murnane, R. J., (Eds.). Whither opportunity. (p. 91-116). New York, NY: Russel Sage Foundation.

Reschovsky, A., \& Imazeki, J. (2001). Achieving educational adequacy through school finance reform. Journal of Education Finance, 26(4), 373-396.

Ronfeldt, M., Loeb, S., \& Wyckoff, J. (2013). How teacher turnover harms student achievement. American Educational Research Journal, 50(1), 4-36.

Roza, M. (2005). Strengthening Title I to help high-poverty schools: How Title I funds fit into district allocation patterns. Seattle: Center on Reinventing Public Education, University of Washington.

Roza, M. (2008). What if we closed the comparability loophole? Seattle: Center on Reinventing Public Education, University of Washington.

Roza, M., \& Hill, P. (2004). How within-district spending inequities help some schools to fail. Brookings Papers on Education Policy, 201-227.

Sass, T. R., Hannaway, J., Xu, Z., Figlio, D. N., \& Feng, L. (2010). Value added of teachers in high-poverty schools and lower poverty schools. Journal of Urban Economics, 72, 104122.

Scafidi, B., Sjoquist, D. L., \& Stinebrickner, T. R. (2007). Race, poverty, and teacher mobility. Economics of Education Review, 26(2), 145-159.

Roza, M., Miller, L., \& Hill, P. (2005). Strengthening Title I to help high-poverty schools: How Title I funds fit into district allocation patterns. Seattle, WA: Center on Reinventing Public Education, University of Washington.

Senate Bill 8. Texas Education Code $\$ 21.157$. Necessary reduction of personnel. Changes added by Acts 2011, 82nd Leg., 1st C.S., Ch. 8 (S.B. 8), Sec. 5, eff. September 28, 2011.

Spatig-Amerikaner, A. (2012). Unequal education: Federal loophole enables lower spending on students of color. Washington, D.C.: Center for American Progress.

Taylor, L. L., \& Fowler Jr, W. J. (2006). A comparable wage approach to geographic cost adjustment. Research and Development Report. NCES-2006-321. National Center for Education Statistics.

Texas Taxpayers and Research Association. (2012). An introduction to school finance in Texas. Austin, TX: Author.

Ujifusa, A. \& Klein, A. (2016, March). ESSA rulemaking: A guide to negotiations. Education Week, 35(24), 14-15.

U. S. Department of Education. (2016). Final regulations. Docket ID ED-2016-OESE-0032. Retrieved from: https://ed.gov/policy/elsec/leg/essa/essaaccountstplans1129.pdf

U. S. Department of Education. (2014). State plans to ensure equitable access to excellent educators - frequently asked questions. Retrieved from https://www.gpo.gov/fdsys/pkg/FR-2014-11-10/pdf/2014-26456.pdf.

U.S. Department of Education, Office of the Under Secretary, Planning and Evaluation Service. (2000). Study of education resources and federal funding: Final report. Washington, DC: Author

Winkler, A. M. \& Zeehandelaar, D. (2012). How strong are US teacher unions? A state-by-state comparison. Washington, D.C.: Thomas B. Fordham Institute. 
Wrabel, S. L., Saultz, A., Polikoff, M. S., McEachin, A., \& Duque, M. (2016). The politics of elementary and secondary education act waivers. Educational Policy, 1-24, DOI: $10.1177 / 0895904816633048$.

Wright v. State of New York. (2014, November). Plaintiffs' amended complaint for declaratory injunction relief. Retrieved from http://edjustice.org/wp-content/uploads/2014/04/WrightPlaintiffs-Amended-Complaint-for-Declaratory-and-....pdf 


\section{Table and Figures}

\section{FIGURE 1}

Average funding per student for teacher salaries and average percent of novice teachers in the highest and lower poverty elementary schools within districts (largest 1,000 districts nationally)
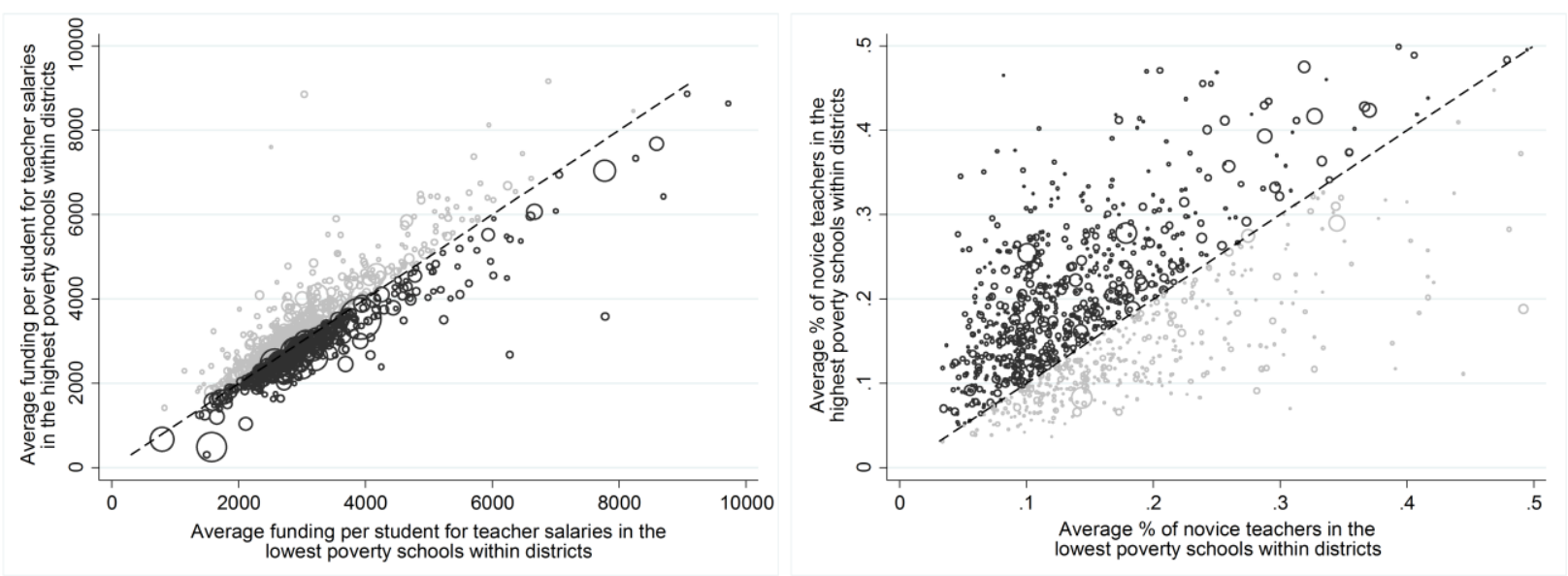

Equitable distribution $\mathrm{O}$ Inequitable distribution

Note. Each circle represents a school district, with size proportionate to district enrollment. Dark grey circles indicate districts in which the highest-poverty elementary schools receive less funding per student for teacher salaries (left side) or have more experienced teachers (right side) than the lowest-poverty elementary schools in the same district. The sample is restricted to the largest 1,000 districts in the country (those with at least approximately 8,000 students). Lowest- and highest-poverty elementary schools are those in the bottom and top quartile of \% FRL, respectively. 


\section{FIGURE 2}

The relationship between elementary school poverty level and teacher resources per student (mean-centered within districts), for otherwise similar districts receiving above state average funding and below state average funding per student
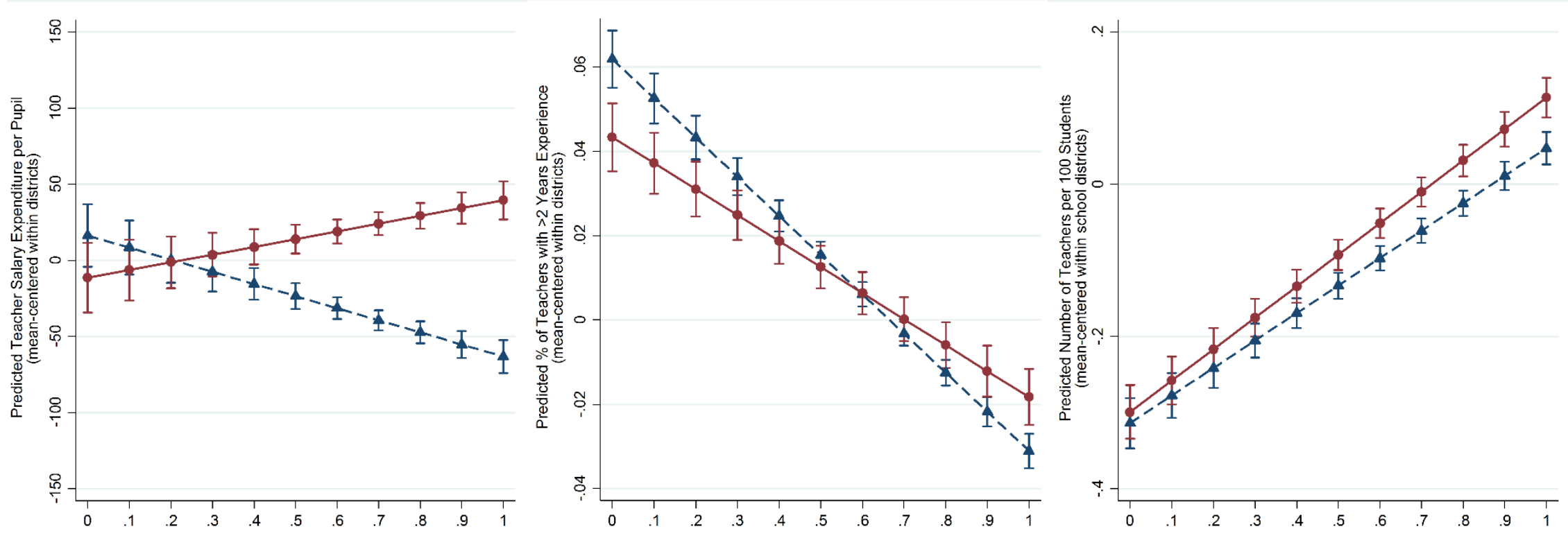

$\%$ Free/Reduced Price Lunch (school-level)

\section{- - - - Districts receiving $15 \%$ less funding per student than the state mean \\ Districts receiving $15 \%$ more funding per student than the state mean}

Note. District funding is adjusted for factors affecting the cost of education including the local cost of labor, district poverty rate, district size, and urbanicity. The sample is limited to elementary schools in districts with at least three other elementary schools. 
TABLE 1

Summary statistics of teacher resources (mean, interquartile range, and intraclass correlation)

\begin{tabular}{|c|c|c|c|}
\hline & Elementary & Middle school & High school \\
\hline $\begin{array}{l}\text { Teacher salary funding } \\
\text { per student }\end{array}$ & $\begin{array}{c}\$ 3,176 \\
{[\$ 2,485, \quad \$ 3,528]} \\
0.546\end{array}$ & $\begin{array}{c}\$ 3,003 \\
{[\$ 2,424, \quad \$ 3,295]} \\
0.694\end{array}$ & $\begin{array}{c}\$ 3,243 \\
{[\$ 2,373, \quad \$ 3,615]} \\
0.451\end{array}$ \\
\hline $\begin{array}{l}\text { Number of teachers per } \\
100 \text { students }\end{array}$ & $\begin{array}{c}5.72 \\
{\left[\begin{array}{c}4.66, \\
0.58\end{array}\right]} \\
0.392\end{array}$ & $\begin{array}{c}5.61 \\
{[4.69, \quad 6.33]} \\
0.475\end{array}$ & $\begin{array}{c}5.70 \\
{\left[\begin{array}{c}4.32, \\
0.42\end{array}\right]} \\
0.238\end{array}$ \\
\hline $\begin{array}{l}\text { Average percent of } \\
\text { teachers with }>2 \text { years of } \\
\text { experience }\end{array}$ & $\begin{array}{c}81.0 \% \\
{[76.7 \%, \quad 89.5 \%]} \\
0.083\end{array}$ & $\begin{array}{c}81.4 \% \\
{[76.7 \%, \quad 90.2 \%]} \\
0.098\end{array}$ & $\begin{array}{c}83.4 \% \\
{[79.5 \%, \quad 92.2 \%]} \\
0.210\end{array}$ \\
\hline
\end{tabular}

Note. Each cell shows the mean, interquartile range, and intraclass correlation of teacher resources. Intraclass correlations show the extent to which observations are correlated within states (higher intraclass correlations imply that values within states are grouped such that some states generally have higher values, while other states generally have lower values). For elementary schools, the sample is limited to schools in districts with at least three other elementary schools in the same district (i.e., districts with at least four elementary schools). The same sample restrictions apply to analyses of middle schools and high schools. We limit the sample for this table so that numbers are comparable to those presented in Table 5; however, these summary statistics are similar when all schools are included. 


\section{TABLE 2}

Regression coefficients predicting the school-level per-pupil state and local expenditures on teachers (Panel A), staff members per 100 students (Panel B), and percent of teachers with three or more years of experience (Panel C)

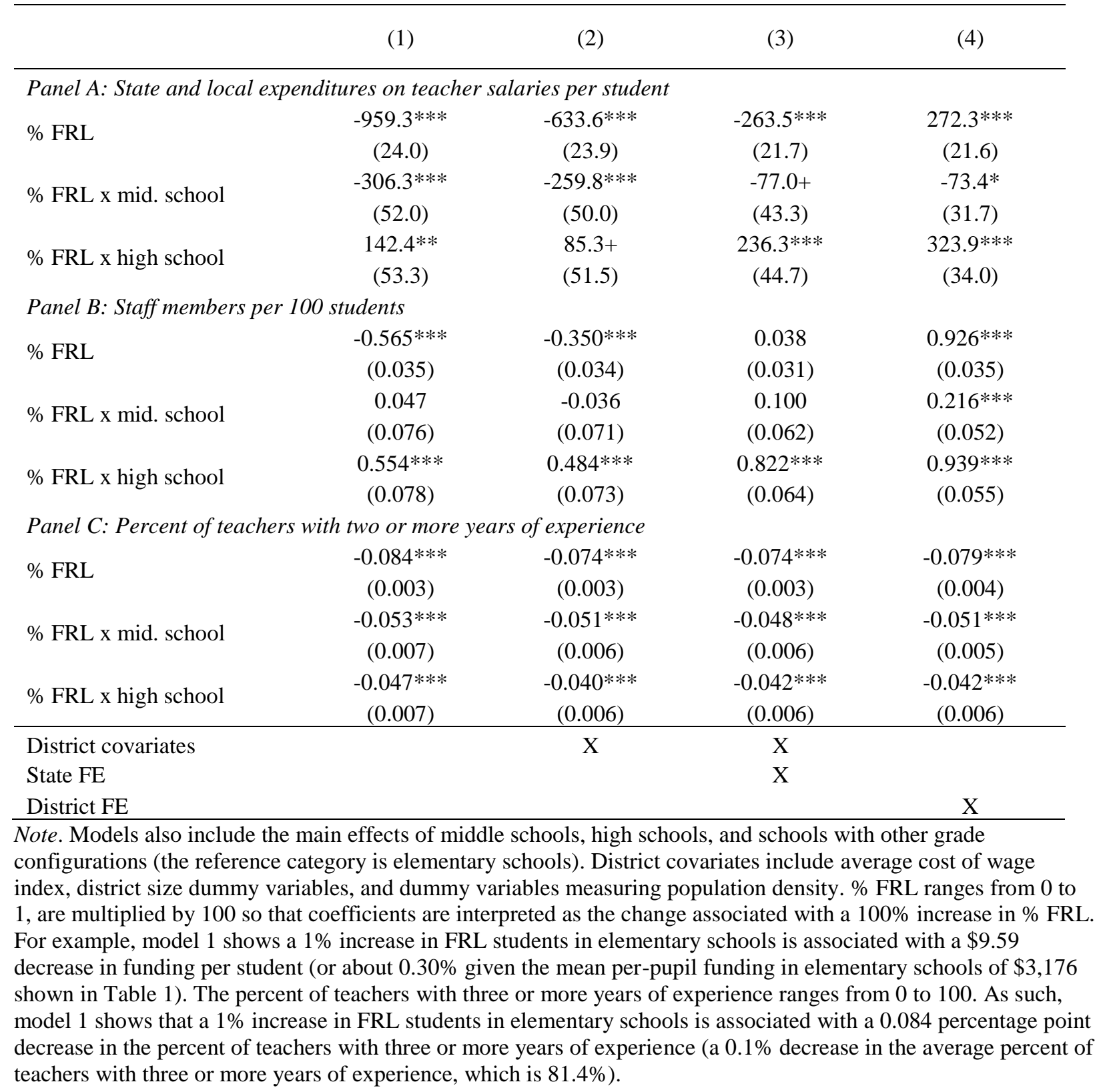




\section{TABLE 3}

Summary statistics of within-district teacher resource gaps (mean, interquartile range, and intraclass correlation) that demonstrate the relationship between poverty/race concentration and the distribution of instructional resources

\begin{tabular}{|c|c|c|c|c|}
\hline & & Elementary & Middle school & High school \\
\hline \multirow{6}{*}{$\begin{array}{l}\text { Gap in teacher } \\
\text { salary spending } \\
\text { per student }\end{array}$} & & $-\$ 36$ & $-\$ 235$ & $-\$ 570$ \\
\hline & $\%$ FRL & {$[-\$ 284, \quad \$ 224]$} & {$[-\$ 402, \quad \$ 94]$} & {$\left[\begin{array}{ll}-\$ 930, & \$ 82\end{array}\right]$} \\
\hline & & 0.040 & 0.000 & 0.002 \\
\hline & & $\$ 21$ & $-\$ 246$ & $-\$ 432$ \\
\hline & $\%$ URM & {$[-\$ 207, \quad \$ 238]$} & {$[-\$ 360, \quad \$ 147]$} & {$[-\$ 849, \quad \$ 187]$} \\
\hline & & 0.023 & 0.000 & 0.020 \\
\hline \multirow{6}{*}{$\begin{array}{l}\text { Gap in number } \\
\text { of teachers per } \\
100 \text { students }\end{array}$} & & -0.33 & -0.55 & -0.92 \\
\hline & $\%$ FRL & {$[-0.78, \quad 0.14]$} & {$\left[\begin{array}{ll}-0.97, & -0.07\end{array}\right]$} & {$[-1.76, \quad 0.07]$} \\
\hline & & 0.025 & 0.013 & 0.019 \\
\hline & & -0.21 & -0.46 & -0.78 \\
\hline & $\%$ URM & {$[-0.62, \quad 0.17]$} & {$[-0.88, \quad 0.04]$} & {$[-1.62, \quad 0.11]$} \\
\hline & & 0.034 & 0.039 & 0.018 \\
\hline \multirow{6}{*}{$\begin{array}{l}\text { Gap in } \% \text { of } \\
\text { teachers with } \\
>2 \text { years of } \\
\text { experience }\end{array}$} & & 0.0315 & 0.0563 & 0.0461 \\
\hline & $\%$ FRL & {$[-1.2 \%, \quad 8.4 \%]$} & {$[0.5 \%, \quad 10.1 \%]$} & {$[0.1 \%, 10.5 \%]$} \\
\hline & & 0.009 & 0.000 & 0.000 \\
\hline & & 0.0423 & 0.0618 & 0.0553 \\
\hline & $\% \mathrm{URM}$ & {$[0.0 \%, 8.2 \%]$} & {$[0.7 \%, 11.1 \%]$} & {$[-0.3 \%, \quad 10.1 \%]$} \\
\hline & & 0.027 & 0.091 & 0.000 \\
\hline
\end{tabular}

Note. Each cell shows the mean, interquartile range, and intraclass correlation of teacher resource gaps. Intraclass correlations show the extent to which observations are correlated within states. Teacher resources gaps are defined as the difference between the top and bottom quartile of schools in terms of the percent of free/reduced price lunch students (\% FRL) and the percent of students at the school who identify as an underrepresented minority (\% URM). Positive numbers indicate that schools with the highest \% FRL or \% URM in their district have fewer teacher resources. For example, on average, elementary schools in the highest quartile of FRL within their district receive \$36 more (a negative gap) per student in state and local funding for teacher salaries, compared to schools in the lowest quartile of FRL in that same district. For elementary schools, the sample is limited to schools in districts with at least three other elementary schools in the same district (i.e., districts with at least four elementary schools). The same sample restrictions apply to analyses of middle schools and high schools. 
TABLE 4

Regression coefficients predicting district-level teacher resource gaps across elementary schools

\begin{tabular}{|c|c|c|c|c|c|c|}
\hline & \multicolumn{3}{|c|}{$\begin{array}{l}\text { Teacher resource gaps by } \\
\text { school poverty rate }\end{array}$} & \multicolumn{3}{|c|}{$\begin{array}{c}\text { Teacher resource gaps by } \\
\text { school \% students of color }\end{array}$} \\
\hline & (1) & (2) & (3) & (4) & (5) & (6) \\
\hline \multicolumn{7}{|c|}{ Panel A: Gap in teacher salary funding per student } \\
\hline $\begin{array}{l}\text { State and local funding } \\
\text { per pupil }\end{array}$ & $\begin{array}{c}-17.29 * * \\
(5.78)\end{array}$ & $\begin{array}{c}-29.04 * * * \\
(6.96)\end{array}$ & $\begin{array}{l}-21.25^{*} \\
(10.07)\end{array}$ & $\begin{array}{c}-10.68+ \\
(6.01)\end{array}$ & $\begin{array}{c}-26.74 * * * \\
(7.28)\end{array}$ & $\begin{array}{c}-31.02 * * \\
(9.95)\end{array}$ \\
\hline Segregation index & $\begin{array}{l}-14.87 \\
(74.43)\end{array}$ & $\begin{array}{c}5.47 \\
(74.36)\end{array}$ & $\begin{array}{c}-9.69 \\
(105.12)\end{array}$ & $\begin{array}{c}-145.94 * \\
(69.99)\end{array}$ & $\begin{array}{l}-100.65 \\
(71.07)\end{array}$ & $\begin{array}{c}-34.91 \\
(103.20)\end{array}$ \\
\hline Poverty rate & $\begin{array}{c}927.28 * * * \\
(142.49)\end{array}$ & $\begin{array}{c}881.37 * * * \\
(144.32)\end{array}$ & $\begin{array}{c}830.16^{* * * *} \\
(210.44)\end{array}$ & $\begin{array}{c}555.23 * * * \\
(141.83)\end{array}$ & $\begin{array}{c}641.24 * * * \\
(144.81)\end{array}$ & $\begin{array}{r}588.27 * * \\
(203.33)\end{array}$ \\
\hline R-squared & 0.050 & 0.137 & 0.560 & 0.022 & 0.106 & 0.585 \\
\hline \multicolumn{7}{|c|}{ Panel B: Gap in number of teachers per 100 students } \\
\hline $\begin{array}{l}\text { State and local funding } \\
\text { per pupil }\end{array}$ & $\begin{array}{l}-0.011 \\
(0.008)\end{array}$ & $\begin{array}{l}-0.025^{*} \\
(0.010)\end{array}$ & $\begin{array}{l}-0.030^{*} \\
(0.013)\end{array}$ & $\begin{array}{l}-0.007 \\
(0.008)\end{array}$ & $\begin{array}{c}-0.025^{* *} \\
(0.010)\end{array}$ & $\begin{array}{c}-0.021+ \\
(0.012)\end{array}$ \\
\hline Segregation index & $\begin{array}{c}-0.698 * * * \\
(0.103)\end{array}$ & $\begin{array}{c}-0.626 * * * \\
(0.105)\end{array}$ & $\begin{array}{c}-0.397 * * \\
(0.141)\end{array}$ & $\begin{array}{c}-0.865^{* * *} \\
(0.091)\end{array}$ & $\begin{array}{c}-0.828^{* * *} \\
(0.094)\end{array}$ & $\begin{array}{c}-0.466 * * * \\
(0.127)\end{array}$ \\
\hline Poverty rate & $\begin{array}{l}1.640 * * * \\
(0.197)\end{array}$ & $\begin{array}{c}1.635^{* * *} \\
(0.204)\end{array}$ & $\begin{array}{l}1.076^{* * * *} \\
(0.279)\end{array}$ & $\begin{array}{c}1.068 * * * \\
(0.184)\end{array}$ & $\begin{array}{c}1.130 * * * \\
(0.192)\end{array}$ & $\begin{array}{c}0.941 * * * \\
(0.250)\end{array}$ \\
\hline R-squared & 0.106 & 0.149 & 0.287 & 0.080 & 0.125 & 0.649 \\
\hline \multicolumn{7}{|c|}{ Panel C: Gap in \% of teachers with >2 years of experience } \\
\hline $\begin{array}{l}\text { State and local funding } \\
\text { per pupil }\end{array}$ & $\begin{array}{c}-0.005^{* * *} \\
(0.001)\end{array}$ & $\begin{array}{l}-0.004 * \\
(0.002)\end{array}$ & $\begin{array}{l}-0.006^{*} \\
(0.003)\end{array}$ & $\begin{array}{l}-0.001 \\
(0.001)\end{array}$ & $\begin{array}{l}-0.002 \\
(0.002)\end{array}$ & $\begin{array}{l}0.001 \\
(0.003)\end{array}$ \\
\hline Segregation index & $\begin{array}{c}0.054 * * \\
(0.017)\end{array}$ & $\begin{array}{l}0.043^{*} \\
(0.018)\end{array}$ & $\begin{array}{l}0.057 * \\
(0.024)\end{array}$ & $\begin{array}{c}0.060 * * * \\
(0.014)\end{array}$ & $\begin{array}{c}0.066^{* * * *} \\
(0.014)\end{array}$ & $\begin{array}{c}0.03 \\
(0.021)\end{array}$ \\
\hline Poverty rate & $\begin{array}{l}-0.033 \\
(0.033)\end{array}$ & $\begin{array}{l}-0.023 \\
(0.035)\end{array}$ & $\begin{array}{l}-0.04 \\
(0.051)\end{array}$ & $\begin{array}{l}-0.01 \\
(0.028)\end{array}$ & $\begin{array}{c}0.012 \\
(0.030)\end{array}$ & $\begin{array}{l}0.027 \\
(0.045)\end{array}$ \\
\hline R-squared & 0.086 & 0.175 & 0.706 & 0.142 & 0.225 & 0.726 \\
\hline Districts covariates & $\mathrm{X}$ & $\mathrm{X}$ & $\mathrm{X}$ & $\mathrm{X}$ & $\mathrm{X}$ & $\mathrm{X}$ \\
\hline State covariates & $\mathrm{X}$ & & & $\mathrm{X}$ & & \\
\hline State fixed effects & & $\mathrm{X}$ & & & $\mathrm{X}$ & \\
\hline County fixed effects & & & $\mathrm{X}$ & & & $\mathrm{X}$ \\
\hline
\end{tabular}

Note. The outcome for models in Panel A is the difference in the average per-pupil state and local spending for teacher salaries between elementary schools in the top quartile of percent of students eligible for free or reduced price lunch (FRL) within the district and elementary schools in the bottom quartile of percent FRL. Gaps are positive when high-poverty schools receive less resources per student. The outcome for Panel B is the gap in the number of teachers per 100 students between high- and low-poverty elementary schools within districts. The outcome for Panel $\mathrm{C}$ is the teacher experience gap between high- and low-poverty elementary schools within districts. The sample is restricted to districts with at least four elementary schools. Results are consistent when comparing the top and bottom half of percent FRL within districts (and expand the sample to districts with at least two elementary schools). Results are also consistent when I exchange state and local funding per pupil with average teacher salaries per pupil or with district per-pupil expenditures. State and local funding per pupil is in $\$ 1,000$ units. Other district covariates include district poverty rate, urbanicity, a cost of labor index, log enrollment, and the average percent of teachers with more than two years of experience (results are consistent if I remove controls for teacher experience). State covariates include average poverty rate across school districts within the state, average spending per pupil across districts, and the relative strength of teacher unions, according to the rankings shown in Winkler and Zeehandelaar, 2012). 
APPENDIX TABLE A1

\section{Appendix}

Regression coefficients predicting the relationship between school-level teacher resources and the percent of student who identify as an underrepresented minority (models 1 and 2) and whether the school is designated as Title I (models 3 and 4)

(1)

(2)

(3)

(4)

\begin{tabular}{|c|c|c|c|c|}
\hline \multicolumn{5}{|c|}{ Panel A: State and local expenditures on teachers per student } \\
\hline $\begin{array}{l}\% \text { URM (model } 1 \text { and 2) or } \\
\text { Title I (model } 3 \text { and 4) }\end{array}$ & $\begin{array}{c}-442.9 * * * \\
(20.7)\end{array}$ & $\begin{array}{c}250.7 * * * \\
(24.2)\end{array}$ & $\begin{array}{c}-125.830 * * * \\
(17.262)\end{array}$ & $\begin{array}{l}10.897 \\
(11.648)\end{array}$ \\
\hline $\begin{array}{l}\text { \% URM or Title I } \\
\text { x mid. school }\end{array}$ & $\begin{array}{c}-103.6^{*} \\
(43.8)\end{array}$ & $\begin{array}{c}-98.5 * * * \\
(26.5)\end{array}$ & $\begin{array}{c}24.308 \\
(32.706)\end{array}$ & $\begin{array}{l}22.938 \\
(19.894)\end{array}$ \\
\hline $\begin{array}{l}\text { \% URM or Title I } \\
x \text { high school }\end{array}$ & $\begin{array}{l}-29.5 \\
(41.8)\end{array}$ & $\begin{array}{l}-12.9 \\
(26.1)\end{array}$ & $\begin{array}{c}131.482^{* * *} \\
(29.679)\end{array}$ & $\begin{array}{l}137.021 * * * \\
(18.777)\end{array}$ \\
\hline \multicolumn{5}{|c|}{ Panel B: Teachers per 100 students } \\
\hline$\%$ URM or Title I & $\begin{array}{c}-1.022 * * * \\
(0.030)\end{array}$ & $\begin{array}{c}1.012 * * * \\
(0.040)\end{array}$ & $\begin{array}{c}0.379 * * * \\
(0.03)\end{array}$ & $\begin{array}{l}0.171^{* * *} \\
(0.02)\end{array}$ \\
\hline $\begin{array}{l}\text { \% URM or Title I } \\
\text { x mid. school }\end{array}$ & $\begin{array}{c}0.312 * * * \\
(0.063)\end{array}$ & $\begin{array}{l}0.094 * \\
(0.043)\end{array}$ & $\begin{array}{l}-0.016 \\
(0.047)\end{array}$ & $\begin{array}{l}0.072 * \\
(0.033)\end{array}$ \\
\hline $\begin{array}{l}\text { \% URM or Title I } \\
x \text { high school }\end{array}$ & $\begin{array}{c}-0.243 * * * \\
(0.060)\end{array}$ & $\begin{array}{l}(0.046) \\
(0.043)\end{array}$ & $\begin{array}{l}0.090 * \\
(0.043)\end{array}$ & $\begin{array}{l}0.210 * * * \\
(0.031)\end{array}$ \\
\hline \multicolumn{5}{|c|}{ Panel C: Percent of teachers with three or more years of experience } \\
\hline$\%$ URM or Title I & $\begin{array}{c}-0.077 * * * \\
(0.003)\end{array}$ & $\begin{array}{c}-0.121 * * * \\
(0.004)\end{array}$ & $\begin{array}{c}-0.024 * * * \\
(0.002)\end{array}$ & $\begin{array}{l}-0.012 * * * \\
(0.002)\end{array}$ \\
\hline $\begin{array}{l}\text { \% URM or Title I } \\
\text { x mid. school }\end{array}$ & $\begin{array}{c}-0.029 * * * \\
(0.006)\end{array}$ & $\begin{array}{c}-0.037 * * * \\
(0.004)\end{array}$ & $\begin{array}{c}-0.018^{* * *} \\
(0.004)\end{array}$ & $\begin{array}{l}-0.017 * * * \\
(0.003)\end{array}$ \\
\hline $\begin{array}{l}\text { \% URM or Title I } \\
x \text { high school }\end{array}$ & $\begin{array}{c}-(0.006) \\
(0.005)\end{array}$ & $\begin{array}{c}-0.023^{* * *} \\
(0.004) \\
\end{array}$ & $\begin{array}{c}-0.012 * * \\
(0.004)\end{array}$ & $\begin{array}{l}-0.013 * * * \\
(0.003)\end{array}$ \\
\hline Coefficient of interest & $\% \mathrm{URM}$ & $\%$ URM & Title I & Title I \\
\hline District covariates & $\mathrm{X}$ & & $\mathrm{X}$ & \\
\hline State fixed effects & $\mathrm{X}$ & & $\mathrm{X}$ & \\
\hline District fixed effects & & $\mathrm{X}$ & & $\mathrm{X}$ \\
\hline
\end{tabular}

Note. The coefficients for models 1 and 2 are for \% URM, while the coefficients for models 3 and 5 are indicators for Title I schools. These models are identical to those shown in Table 3, except that I substitute \% FRL with \% of students of color (models 1 and 2) and an indicator for Title I schools (models 3 and 4). Other district covariates (not shown, but included in models 1 and 3) include average cost of wage index, district size dummy variables, and dummy variables measuring population density. 


\section{APPENDIX TABLE A2}

Regression coefficients predicting the school-level per-pupil state and local expenditures on teachers (Panel A), staff members per 100 students (Panel B), and percent of teachers with three or more years of experience (Panel C), by the proportion of Title I schools in the district

\begin{tabular}{|c|c|c|c|c|c|c|}
\hline & \multicolumn{3}{|c|}{$\begin{array}{l}\text { Districts with at least one, } \\
\text { but not all Title I schools }\end{array}$} & \multicolumn{3}{|c|}{ Districts with all Title I schools } \\
\hline \multicolumn{7}{|c|}{ Panel A: State and local expenditures on teachers per student } \\
\hline$\% \mathrm{FRL}$ & $\begin{array}{c}-594.6 * * * \\
(25.00)\end{array}$ & $\begin{array}{c}-142.0 * * * \\
(22.70)\end{array}$ & $\begin{array}{l}273.1 * * * \\
(22.80)\end{array}$ & $\begin{array}{c}-2073.6 * * * \\
(57.10)\end{array}$ & $\begin{array}{c}-724.8 * * * \\
(54.60)\end{array}$ & $\begin{array}{l}339.3 * * * \\
(64.40)\end{array}$ \\
\hline$\%$ FRL x mid. school & $\begin{array}{c}-376.7 * * * \\
(55.50)\end{array}$ & $\begin{array}{l}-88.7+ \\
(46.50)\end{array}$ & $\begin{array}{l}-70.3+ \\
(36.50)\end{array}$ & $\begin{array}{c}-102.0 \\
(116.20)\end{array}$ & $\begin{array}{c}-64.1 \\
(97.40)\end{array}$ & $\begin{array}{c}-220.8 * * * \\
(66.90)\end{array}$ \\
\hline$\%$ FRL x high school & $\begin{array}{l}182.9 * * \\
(57.90)\end{array}$ & $\begin{array}{c}320.4 * * * \\
(48.60)\end{array}$ & $\begin{array}{c}368.6 * * * \\
(38.90)\end{array}$ & $\begin{array}{l}311.5 * * \\
(113.80)\end{array}$ & $\begin{array}{c}94.7 \\
(97.00)\end{array}$ & $\begin{array}{c}74.6 \\
(71.40)\end{array}$ \\
\hline \multicolumn{7}{|c|}{ Panel B: Staff members per 100 students } \\
\hline$\% \mathrm{FRL}$ & $\begin{array}{c}-0.204 * * * \\
(0.04)\end{array}$ & $\begin{array}{c}0.282 * * * \\
(0.03)\end{array}$ & $\begin{array}{l}0.978 * * * \\
(0.04)\end{array}$ & $\begin{array}{c}-1.823 * * * \\
(0.08)\end{array}$ & $\begin{array}{c}-0.534 * * * \\
(0.08)\end{array}$ & $\begin{array}{c}0.789 * * * \\
(0.11)\end{array}$ \\
\hline$\%$ FRL x mid. school & $\begin{array}{c}-0.193 * \\
(0.08)\end{array}$ & $\begin{array}{c}0.01 \\
(0.07)\end{array}$ & $\begin{array}{c}0.176^{* *} \\
(0.06)\end{array}$ & $\begin{array}{c}0.334 * \\
(0.16)\end{array}$ & $\begin{array}{l}0.159 \\
(0.14)\end{array}$ & $\begin{array}{l}0.076 \\
(0.11)\end{array}$ \\
\hline$\%$ FRL x high school & $\begin{array}{l}0.192 * \\
(0.09)\end{array}$ & $\begin{array}{c}0.802 * * * \\
(0.07)\end{array}$ & $\begin{array}{l}0.885 * * * \\
(0.06)\end{array}$ & $\begin{array}{c}1.081 * * * \\
(0.16)\end{array}$ & $\begin{array}{c}0.647 * * * \\
(0.14)\end{array}$ & $\begin{array}{c}0.724 * * * \\
(0.12)\end{array}$ \\
\hline \multicolumn{7}{|c|}{ Panel C: Percent of teachers with three or more years of experience } \\
\hline$\% \mathrm{FRL}$ & $\begin{array}{c}-0.079 * * * \\
(0.00)\end{array}$ & $\begin{array}{c}-0.071 * * * \\
(0.00)\end{array}$ & $\begin{array}{c}-0.078^{* * *} \\
(0.00)\end{array}$ & $\begin{array}{c}-0.112 * * * \\
(0.01)\end{array}$ & $\begin{array}{c}-0.090 * * * \\
(0.01)\end{array}$ & $\begin{array}{c}-0.075 * * * \\
(0.01)\end{array}$ \\
\hline$\%$ FRL x mid. school & $\begin{array}{c}-0.049 * * * \\
(0.01)\end{array}$ & $\begin{array}{c}-0.046^{* * * *} \\
(0.01)\end{array}$ & $\begin{array}{c}-0.057 * * * \\
(0.01)\end{array}$ & $\begin{array}{c}-0.050 * * \\
(0.02)\end{array}$ & $\begin{array}{c}-0.033 * \\
(0.01)\end{array}$ & $\begin{array}{l}-0.017 \\
(0.01)\end{array}$ \\
\hline$\%$ FRL x high school & $\begin{array}{c}-0.045 * * * \\
(0.01)\end{array}$ & $\begin{array}{c}-0.048 * * * \\
(0.01) \\
\end{array}$ & $\begin{array}{c}-0.051 \text { *** } \\
(0.01)\end{array}$ & $\begin{array}{c}-0.035^{*} \\
(0.02) \\
\end{array}$ & $\begin{array}{r}-0.013 \\
(0.01) \\
\end{array}$ & $\begin{array}{l}-0.003 \\
(0.01) \\
\end{array}$ \\
\hline District covariates & & $\mathrm{X}$ & & & $\mathrm{X}$ & \\
\hline State fixed effects & & $\mathrm{X}$ & & & $\mathrm{X}$ & \\
\hline District fixed effects & & & $\mathrm{X}$ & & & $\mathrm{X}$ \\
\hline
\end{tabular}

Note. District covariates include average cost of wage index, district size dummy variables, and dummy variables measuring urbanicity. A total of 531 districts have no Title I schools (3.7\% of all districts), which comprise 880 schools (1.1\% of all schools) and 331,819 students ( $0.7 \%$ of all students). 


\section{TABLE A3}

Regression coefficients predicting the school-level per-pupil state and local expenditures on teachers (Panel A), staff members per 100 students (Panel B), and percent of teachers with three or more years of experience (Panel C), for districts with at least four elementary schools (columns 1-2), middle schools (columns 3-4), or high schools (columns 5-6)

\begin{tabular}{|c|c|c|c|c|c|c|}
\hline & \multicolumn{2}{|c|}{$\begin{array}{l}\text { Districts with at least four } \\
\text { elementary schools }\end{array}$} & \multicolumn{2}{|c|}{$\begin{array}{l}\text { Districts with at least four } \\
\text { middle schools }\end{array}$} & \multicolumn{2}{|c|}{$\begin{array}{c}\text { Districts with at least four } \\
\text { high schools }\end{array}$} \\
\hline \multicolumn{7}{|c|}{ Panel A: State and local expenditures on teachers per student } \\
\hline$\% \mathrm{FRL}$ & $\begin{array}{c}-640.046 * * * \\
(21.742)\end{array}$ & $\begin{array}{c}133.291 * * * \\
(16.510)\end{array}$ & $\begin{array}{c}-135.384^{* *} \\
(52.496)\end{array}$ & $\begin{array}{c}364.430 * * * \\
(43.751)\end{array}$ & $\begin{array}{c}508.917 * * * \\
(79.399)\end{array}$ & $\begin{array}{c}1069.999 * * * \\
(93.627)\end{array}$ \\
\hline \multicolumn{7}{|c|}{ Panel B: Staff members per 100 students } \\
\hline$\% \mathrm{FRL}$ & $\begin{array}{c}-0.165 * * * \\
(0.029)\end{array}$ & $\begin{array}{c}0.812 * * * \\
(0.026)\end{array}$ & $\begin{array}{c}0.555^{* * *} \\
(0.076)\end{array}$ & $\begin{array}{c}1.409 * * * \\
(0.076)\end{array}$ & $\begin{array}{c}1.220 * * * \\
(0.115)\end{array}$ & $\begin{array}{c}2.348 * * * \\
(0.150)\end{array}$ \\
\hline \multicolumn{7}{|c|}{ Panel C: Percent of teachers with three or more years of experience } \\
\hline$\% \mathrm{FRL}$ & $\begin{array}{c}-0.076^{* * * *} \\
(0.004)\end{array}$ & $\begin{array}{c}-0.084 * * * \\
(0.005)\end{array}$ & $\begin{array}{c}-0.142 * * * \\
(0.008)\end{array}$ & $\begin{array}{c}-0.152 * * * \\
(0.010)\end{array}$ & $\begin{array}{c}-0.114 * * * \\
(0.009) \\
\end{array}$ & $\begin{array}{c}-0.113 * * * \\
(0.012) \\
\end{array}$ \\
\hline $\mathrm{N}$ & 33,992 & 33,992 & 5,548 & 5,548 & 5,002 & 5,002 \\
\hline R-squared & 0.025 & 0.002 & 0.001 & 0.014 & 0.007 & 0.027 \\
\hline District FE & & $\mathrm{X}$ & & $\mathrm{X}$ & & $\mathrm{X}$ \\
\hline
\end{tabular}

Note. Columns 1 and 2 show regressions for elementary schools only, limiting the sample to districts with at least four elementary schools. Columns 3 and 4 repeat the same regressions for middle schools and columns 4 and 6 repeat the same regressions for high schools. 